\title{
DIE SLAG VAN DOORNKRAAL
}

\section{Kmdt CJ Nöthling*}

Contrary to the premise that military historians tend to regard the Battle of Doornkraal as a minor skirmish of the Second Anglo-Boer War, this article expounds the view that the outcome of this brief but violent encounter had far-reaching implications. A detailed account of the events leading up to the British surprise attack on General De Wet's commando forces at dawn on 6th November 1900 is given. As the author points out, De Wet had ample warning of his foe's intentions: his narrow escape at Rensburgdrift was almost a full dress-rehearsal for the tragic act to be played out at Doornkraal. De Wet did not heed this warning, thereby committing perhaps the greatest tactical blunder of his military career. For the British Doornkraal was a major victory, but one for which they had to pay dearly. As things turned out, they lost a few able officers and a tailor-made opportunity to capture President M.T. Steyn and General De Wet. The Boer general swore revenge, and the British had to suffer humiliation and defeat until the end of the war.

\section{INLEIDING}

"My verkenners was my oë en ore", het generaal Christiaan de Wet ná die afloop van die Tweede Vryheidsoorlog (1899-1902) ruiterlik hulde gebring aan legendariese figure soos Danie Theron, Barry Richter en Melt van Schoor. ${ }^{1)}$ Hierdie bekentenis oor die lippe van 'n Boere-generaal wat onsterflike roem op die slagveld verwerf het, dien as ' $n$ skitterende getuigskrif vir die aandeel van De Wet se verkenners in klassieke veldslae soos Sannaspos, Rooiwalstasie en Groenkop. ${ }^{2)}$ Eweneens kan hul rol in generaal De Wet se vele noue ontkomings soos onder meer by Brakrivier en die Brandwaterkom nie geringskat word nie. Die enkele nederlae wat De Wet gedurende die vryheidstryd gely het soos byvoorbeeld dié by Rensburgdrift ${ }^{3)}$ en Doornkraal (Bothaville) kan dan ook daaraan toegeskryf word dat sy verkenners hom nie betyds oor die bewegings van die vyand ingelig het nie.

Die slag van Doornkraal (6 November 1900) word in kronieke oor generaal De Wet veelal verswyg as 'n gebeurtenis van mindere belangrikheid. Dit was weliswaar maar net een van De Wet se nederlae waartydens die vyand weer eens nie daarin kon slaag om hom aan te keer nie. ' $n$ Nadere beskouing van die gebeure by Doornkraal toon egter dat hierdie veldslag allesbehalwe onbeduidend en van geringe betekenis was sover dit generaal De Wet se krygsleiding betref. Andersins werp dit meer lig op sy credo dat sy verkenners ' $n$ onontbeerlike element van sy besondere welslae as militêre aanvoerder uitgemaak het. En dan was die uitslag van hierdie veldslag een met verreikende gevolge: dit het generaal De Wet opnuut gesterk in sy oortuiging dat die bedryf van krygsoperasies deur verspreide en beweeglike formasies teen die Britse oormag die aangewese taktiek was terwyl die vyand uit oorgretigheid 'n oorwinning behaal het waarvoor hy later ten duurste sou betaal. ${ }^{4)}$

\section{DIE VOORSPEL}

Die slag van Doornkraal moet gesien word teen die agtergrond van die Britse opperbevel se volgehoue pogings in 1900 om pres M.T. Steyn en generaal De Wet in hul dryfjagte vas te keer. Berede afdelings van die Britse magte het in Julie 1900 dan ook daarin geslaag om De Wet vanaf Lindley in die Oos-Vrystaat noordwaarts tot in Transvaal te verdryf. Hy het egter ná 'n kort verposing agter die Magaliesberg na die OranjeVrystaat teruggekeer om die stryd aldaar voort te sit. Hoewel hy deur vinnige slae die vyand oral gevoelige verliese toedien, word sy posisie algaande moeiliker want hy kry te doen met 'n vyand wat hom meedoënloos agtervolg en probeer om hom teen die Vaalrivier vas te druk.

Ofskoon afdelings van die Britse magte die meeste driwwe bewaak, ondervind De Wet nie juis probleme om die Vaalrivier oor te steek en tydelike uitvlug in Wes-Transvaal te vind nie. Hier raak hy slaags met ' $n$ onderskeppingsmag onder genl maj G. Barton en hoewel hy Frederikstad beleër, kry Barton versterkings en De Wet moet op 25 Oktober die aftog blaas. Hy word nou knaend agtervolg en twee dae later 'n verdere knou toegedien wanneer hy by Rensburgdrift die Vaalrivier oorsteek. Hierdie kortstondige maar felle skermutseling word soos volg deur De Wet toegelig:

"Wij trokken vroeg den volgenden morgen de Vaalrivier te Witbanksfontein door. Daar zadelden wij af. 
Nou had ik verkenners uit - niet echter van Com. Jan Theron's manschappen maar gewone burgers, die de commandanten uitgezonden hadden; en, toen wij pas een laat ontbijt. tegen den middag genoten hadden kwamen deze burgers in het lager gejaagd, schreeuwende

'Hier is de vijand!'

Het duurde niet lang of elkeen was opgezaald, en wij moesten maar retireeren. De Engelschen hadden de kopjes vlak ten noorden van die Vaalrivier, en wij niets meer dan de muren van de kraal en de landerijen. - Deze leverden geen positie voor onze paarden, en wij moesten uitjagen. Het was ons een warme namiddag zoo te wijken met kanon en geweer bestookt.

Wij verloren hier één kanon. Dit gebeurde terwijl ik in den linkervleugel was. Een der wielen van de affuit viel uit en het kanon moest achtergelaten worden. lets wonderlijks gebeurde ook met deze vlucht. Een granaat van den vijand trof den ossewagen, waarop er vier kasten dynamiet was: en alles werd verpletterd. De ossen waren juist afgehaakt, en de wagen verlaten, anders was er een verschrikkelijke ramp geweest.

Wij hadden verder geen verlies, behalve twee burgers, die, denkende dat het veilig was, om in een huis zich te versteken, juist daar door twee Engelsche machten, die van de richting van Schoemansdrift kwamen, de gelegenheid gaf hen gevangen te nemen. ${ }^{\text {"5) }}$

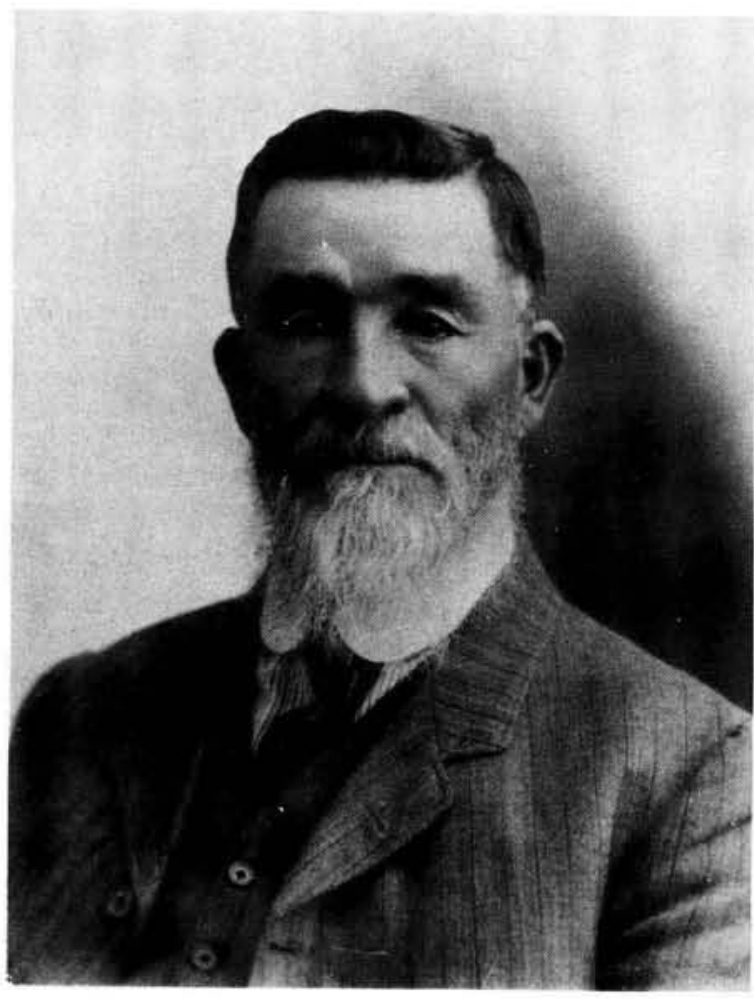

Generaal C.R. de Wet

De Wet het klaarblyklik nog nie begryp dat die skermutseling by Rensburgdrift deel uitgemaak het van 'n beplande maneuver om hom vas te keer nie. In 'n sekere sin was Rensburgdrift ' $n$ onheilspellende kleedrepetisie vir die ramp by Doornkraal waar dieselfde Britse mag onder kol C.E. Knox die kommando van De Wet in soortgelyke omstandighede verras het. ${ }^{6)}$ In dié verband hoef slegs gelet te word op die prominente rol wat twee van Knox se ondergeskikte bevelvoerders, nl It kol P.W.J. le Gallais ${ }^{7)}$ en It kol H. de B. Lisle ${ }^{8)}$, in beide veldslae gespeel het. Dit blyk duidelik uit die amptelike Britse kroniek wat die gebeure by Rensburgdrift soos volg weergee:

"When Sir A. Hunter left Bothaville, Le Gallais' mounted force was ordered to proceed to Reitzburg, for the purpose of cooperating with C.E. Knox. That officer had been instructed by Lord Roberts to move at once from Vredefort Road into the Transvaal, taking with him de Lisle's M.I. (about 700 men, with three guns) and the Colonial Division. The object of the movement was to assist Major-General G. Barton, who was practically invested at Fredrickstad by a large force of the enemy under $C$. De Wet. Before Knox could join hands with him, Barton had been reinforced on October 25 th by a battalion of infantry and 550 mounted men, and had scattered the Boers in all directions. Knox reached Potchefstroom on the 26th, and then received information that De Wet was at Elandsfontein (near Lindequee), with the intention of recrossing the Vaal, and moving on Heilbron. At dawn next morning Knox, with the Colonial Division, moved rapidly in the direction of Rensburg Drift. On the way he heard that De Wet, with 1000 men and six guns, had the day before been pointing towards Schoeman's Drift, but had changed his direction towards Buffelshoek, on finding Le Gallais' force and some infantry waiting for him at Tygerfontein. At 5 p.m. on the 27th, Knox caught the enemy in the act of breaking laager at Rensburg Drift, midway between Venterskroon and Parys, and punished him severely. Not waiting to fight, the Boers broke and fled southwards; but Le Gallais, who had previously been ordered to move on Vredefort via Venterskroon, succeeded in heading them off, and drove them up stream to Parys."

Wat die bostaande bron nie vermeld nie, is die feit dat 'n Australiese kontingent van It kol De Lisle se berede infanteriekorps (wat deel uitgemaak het van 1st Mounted Infantry Brigade onder genl maj E.T.H. Hutton ${ }^{10)}$ maar tot die kolonne van Knox toegevoeg was) die voorhoede gevorm het van die Britse aanval by Rensburgdrift. Dat die uiters beweeglike berede infanterie van De Lisle ' $n$ faktor was waarmee De Wet hom misreken het, blyk uit die volgende opmerking deur L.S. Amery:

"De Lisle's Australians had pressed on so fast that they passed through the Boer rear screen and cut if off from the main body."11)

Tydens sy uitvlug vanaf Rensburgdrift het De Wet aanvanklik in ' $n$ suidoostelike rigting beweeg maar tussen Vredefort en Grooteiland is hy deur It kol Le Gallais voorgekeer en noordwaarts na Parys gedwing. De Wet het nou die gevaar geloop om tussen die stygende Vaalrivier aan sy 
linkerkant en die mag van Le Gallais vasgekeer te word, maar danksy die naderende nag en 'n hewige donderstorm kon hy sy agtervolgers afskud. Gedurende die nag het hy in 'n suidwestelike rigting geswenk en laat die volgende middag Bronkhorstfontein (Witkopjes) bereik. ${ }^{12)}$ Hierna het die kommando 'n westelike koers ingeslaan en tot by Winkelsdrift langs die Rhenosterrivier ${ }^{13)}$ beweeg waar De Wet van pres Steyn se terugkeer vanaf Hectorspruit (Oos-Transvaal) verneem het. ${ }^{14)}$ De Wet, wat deur Steyn versoek is om hom by Ventersdorp te ontmoet, het sy kommando na Bothaville laat trek en self met sy persoonlike staf die gevaarlike tog na WesTransvaal aangepak. Hierdie keer is hy egter gelukkig want die Britse magte het tydelik sy spoor verloor en hy bereik Ventersdorp op 31 Oktober waar pres Steyn reeds vir hom wag. ${ }^{15)}$

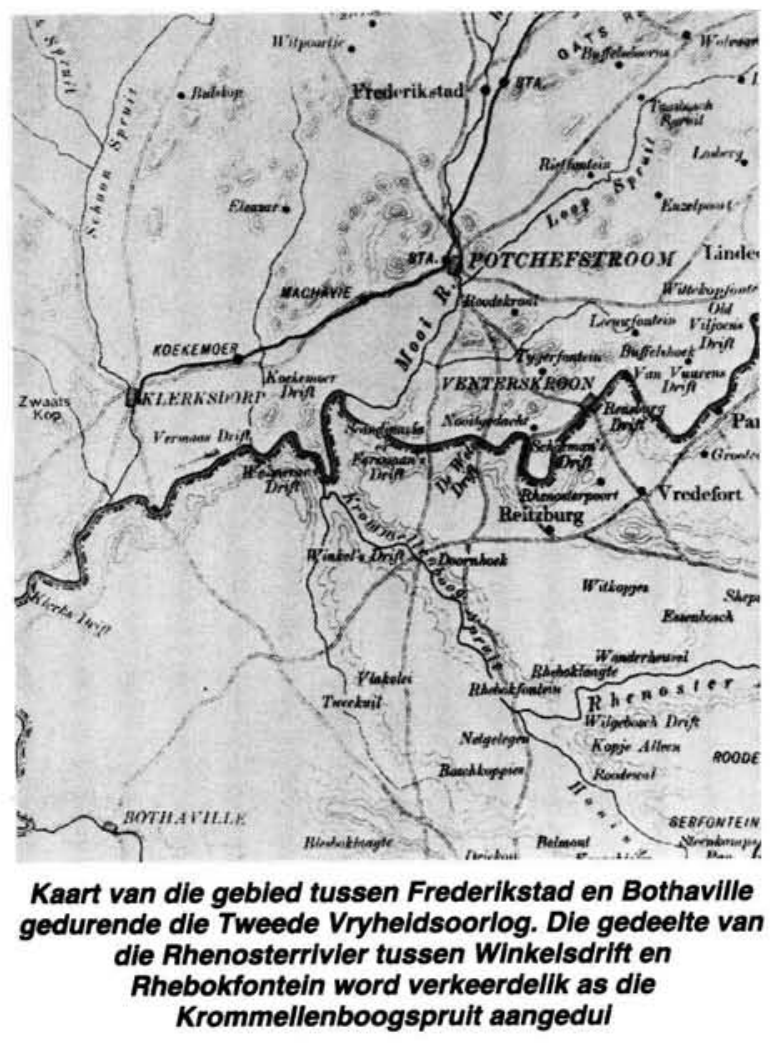

Die nuus wat pres Steyn met hom saamgebring het, kon nouliks slegter wees want in Transvaal, waar hy kort vantevore van pres Kruger afskeid moes neem, was die posisie van die Republikeinse magte uiters benard. Soos in ' $n$ biografiese skets van Steyn vermeld word, was generaal Botha ná die nederlaag by Dalmanutha "baie somber oor voortsetting van die stryd."

Steyn en De Wet is egter nie deur hierdie vlaag van pessimisme wat in Transvaal gewoed het, beïnvloed nie. Tydens hul terugtog, wat op 2 November begin, spreek De Wet selfs sy voorneme uit om die Kaapkolonie in te val! ${ }^{17)}$ Intussen het hy ook van generaals P.J. Fourie en J.B.M. Hertzog berig ontvang dat baie Vrystaatse burgers weer vir aktiewe diens aangemeld het.

Steyn en De Wet het Bothaville op 5 Oktober bereik waar generaal C.C. Froneman reeds angstig op hul terugkeer gewag het. ${ }^{18)}$ Enkele ure ná hul aankoms in die dorp maak ' $n$ vyandelike mag sy verskyning en 'n skermutseling volg. Hierdie mag, wat as 't ware uit die niet verskyn en De Wet op die verkeerde voet by Bothaville betrap het, was weer eens dié van kol Knox wat vanaf die spoorlyn noord van Kroonstad oor 'n wye front ontplooi en weswaarts gevee het in 'n poging om sy verdwene vyand op te spoor. Ná 'n vrugtelose soektog van nege dae het Knox dit eindelik gelukkig getref want It kol Le Gallais op sy suidelike flank het reg op Bothaville afgestuur. Die amptelike Britse kroniek beskryf die daaropvolgende gebeure soos volg:

"Le Gallais, who had with him the 5th, 17th and 18th companies Imperial Yeomanry, the 5th, 7th and 8th battalions M.I. (about 1050 men) and U. battery R.H.A., had moved rapidly on November 5th towards Bothaville, and by noon had reached a point about five miles to the west (sic) of the town. There it was intended to camp while a reconnaissance was pushed forward. In the afternoon, the 5th, supported by the 8th M.I. and two guns $U$. battery, drew towards the right bank of the Valsch River, which flows through Bothaville. A few Boers were seen on the distant skyline across the stream; but they made no reply to a shell which was fired at them, and the British advance guard carefully approached the houses dotted along the right bank. When the mounted screen reached a point within 1000 yards' range of the ridge beyond the river, a single shot was fired, and was immediately followed by a storm of shells and bullets. The advance guard, finding no cover at hand, hastily retired out of range, with only three casualties, and the guns shelled the Boer position until dark. When the moon rose, the 5th M.I. advanced on the town, and finding it unoccupied, pushed on (the 8th M.I. in support) across the river, which was in flood. The ridge, whence the Boers had opened fire, was soon reached and found untenanted (sic?). There the advance troops spent the remaining hours of the night, while the main body of Le Gallais' force, with the baggage, moved up to Bothaville." ${ }^{\text {"19) }}$

Op die dorpsplein, waar die grootste deel van Le Gallais se mag oornag het, is vasgestel dat generaals De Wet en Froneman ure vantevore nog in Bothaville was. Le Gallais het besluit om De Wet se spoor te volg. Gedurende die nag is kol Knox, wat met die hoofmag by Elandsvlei $16 \mathrm{~km}$ noord van die dorp oorgestaan het, verwittig van die skermutseling by Bothaville. Teenstrydige berigte het Knox aanvanklik laat vermoed dat De Wet ' $n$ noordelike koers ingeslaan het, maar Le Gallais se berig het nou alle twyfel uit die weg 
geruim. Hy het besluit om die volgende oggend na Bothaville te versit.

Van al hierdie koorsagtige voorbereidings was generaal De Wet salig onbewus. Asof die skermutseling by Bothaville as ' $n$ laaste waarskuwing nie genoeg was nie, het hy dit veilig geag om op die plaas Doornkraal sowat $8 \mathrm{~km}$ suid van die dorp te oornag. Dat hy min onraad vermoed het, blyk duidelik uit sy eie weergawe:

\begin{abstract}
"Maar ach! wie kon denken dat ons nabij het dorp, een groot onheil wachtte? Dienzelfden namiddag daagde een sterke macht van den vijand, die ons achtervolgd had, op, en een schermutseling vond plaats, waarna de Engelschen terugtrokken, niet verder echter dan onder schot uit. Wij ook trokken weg, maar slechts over den eersten bult. Zonder iets te vreezen, vernachtten wij ongeveer zeven mijlen (sic) van de Engelschen, met de Valschrivier tusschen ons en hen." ${ }^{20)}$
\end{abstract}

Anders as by Rensburgdrift, het De Wet dus nie van die naderende nag gebruik gemaak om verder in ' $n$ suidelike rigting te beweeg nie. In een opsig het dit hierdie keer ook sy ondergang bewerkstellig, want hy het sy verkenners nie uitgestuur om die Britse magte noord van die Valschrivier onder die oog te hou nie. Hy het dit voldoende geag om ' $\mathrm{n}$ brandwag sowat $3 \mathrm{~km}$ suid van die rivier te plaas wat die volgende oggend moes terugrapporteer. ${ }^{21)}$

Om 04h00 die volgende oggend het It kol Le Gallais die soektog na die Boerekommando's hervat. Hoewel dit nog donker was, kon die diep spore wat die Boere se kanonne in die nat grond getrap het, maklik gevolg word. Terwyl die 5th Mounted Infantry onder maj Kenneth Lean ${ }^{22)}$ weggebreek het om die gebied suid van Bothaville te verken, het die 8th Mounted Infantry (Imperial Yeomanry) met drie kanonne van U. Battery (Royal Horse Artillery) die aanmars begin. 'n Deel van Le Gallais se mag het in Bothaville agtergebly om die rivierdrif en die leërtros ${ }^{23)}$ te beveilig.

Die oprukkende kolonne van Le Gallais het nou in die vroeë oggendskemering oor 'n gelyke grasvlakte op die slapende kommando's afgestuur en net die brandwag wat deur De Wet uitgeplaas is, kon hulle teen die naderende onheil waarsku. Maar hierdie brandwag het ook jammerlik in hul taak gefaal want hulle word slapend aangetref en gevange geneem voordat hulle alarm kan maak. ${ }^{24)}$ Die ironie van hierdie noodlottige voorval is dat lede van dié brandwag kort vantevore na Doornkraal teruggekeer het, want De Wet skryf:

"De burgers van deze wacht kwamen in den morgen en rapporteerden dat zij niets zagen dan rookjes. Die rookjes waren ten noorden der rivier, en zij meenden, dat die opstegen uit het lager der Engelschen. 't Was dan nog veilig - zoo zou een ieder kunnen gerneend hebben. ${ }^{25}$ )

Soos L.S. Amery (et al) tereg opmerk, "This lucky stroke decided the fortunes of the day." ${ }^{26)}$ Maj Lean het onmiddellik besef dat hy die kommandomag anderkant die bult sou aantref en 'n boodskap teruggestuur sodat die kanonne van $U$. Battery vorentoe gebring kon word. Hierna het hy en die 67 man onder sy bevel vinnig die gelykte oorgesteek en teen die skuinste voor hulle uitgejaag. En soos hy trouens verwag het, was die Boerelaer skielik voor maj Lean. Soos dit dan ook blyk uit die beskrywing van die amptelike Britse weergawe, was Lean en sy manne ietwat verras oor die vreemde gesig voor hulle:

"Suddenly, as day was breaking, the scouts, topping a low ridge, beheld a strange scene. Below them were grazing herds of oxen and horses, amongst which rode Boers engaged in collecting the beasts for the day's march. Within 300 yards of the British scouts lay De Wet's long-sought laager."27)

Die vreemde toneel waarop maj Lean en sy ruitery afgekyk het, sou enige bevelvoerder voor die versoeking stel om onverwyld 'n verrassingsaanval te loods. Die kamp, waar die meeste van De Wet se 800 burgers nog geslaap het, was sowat 340 meter suidwes van Lean se posisie en dus binne sy skootsveld. Die laer was grotendeels onbeskut en die klipmuur van 'n tuin sowat 90 meter oos daarvandaan het die naaste dekking gebied. Verder sou die Boerekrygers net kon reken op die grondwal van 'n dam wat die tuin se suidoostelike grens uitgemaak het en 'n plaashuis oos van die dam.

Maj Lean het besluit om dadelik tot die aanval oor te gaan. Indien die latere verloop van die slag van Doornkraal in oënskou geneem word, ontstaan die vraag of maj Lean nie dalk oorhaastig opgetree het nie; op daardie tydstip kon die Britse bevelvoerder met die 67 man onder sy bevel kwalik 'n oormag van 800 burgers omsingel terwyl ' $n$ verrassingsaanval slegs ' $n$ tydelike voordeel sou inhou. Afgesien daarvan dat ' $n$ moontlike teenaanval deur De Wet vir Lean en sy dragonders onder groot druk sou plaas, kon die kommando's geredelik maklik ontvlug.

Maj Lean het egter nie genoeg tyd gehad om aan hierdie oorwegings te dink nie. Volgens skrywers soos Arthur Conan Doyle en F. Maurice was die tydsfaktor van kardinale belang en as sodanige het dit Lean geen ander keuse gelaat nie. In hierdie verband skryf Doyle: 


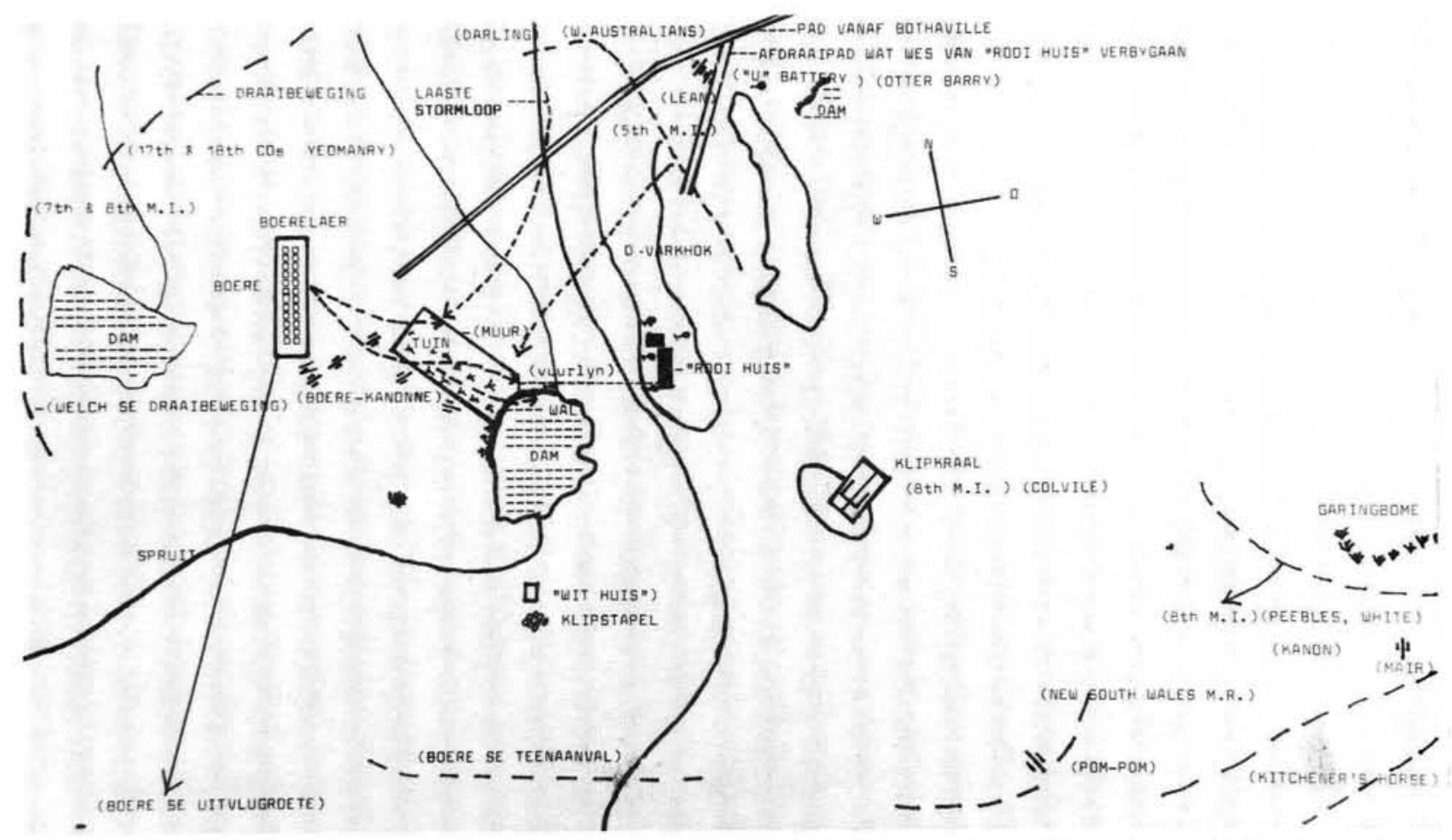

Kaart van dle slagveld te Doornkraal op 6 November 1900 soos gedeeltellk nagetrek van dié van Amery (Vol 5). Aangeslen Amery se kaart aandul dat dle suldwaartse wapad oos van dle 'rool huls' verbygaan (sic) en dle skrywer hlervan verskll, ls dit op dle nagetrekte kaart nle voltool nie. Oorblyfsels van 'n pad wat wes van dle opstal verbygegaan het, is nog op dle plaas KIlpkraal te sien. Dle huidige pad is heelwat verder van die huis en loop digby dle noordoostellke muur verby

"There was little time for consideration. The Kaffir drivers were already afoot and strolling out for their masters' coffee. With splendid decision, although he had but fourty (sic) men to oppose to over a thousand (sic), Lean sent back for reinforcements and opened fire upon the camp."28)

Maj Lean kon nie langer talm nie want daar was reeds heelwat bedrywighede in die laer en die Britse soldate wat oor die noordoostelike gesigseinder versprei was, kon enige oomblik opgemerk word. Volgens Jackson is Lean se ruitery inderdaad op die horison gewaar nog voordat die eerste skoot gevuur is:

"The Boers' Kaffirs were the first to see us, and they ran out to get the horses and mules in. ${ }^{.29)}$

Hierdie waarneming word nie deur amptelike bronne bevestig nie. Generaal De Wet maak ook nie daarvan melding nie en hy het eers onraad bemerk toe die Britse vuurlinie op die laer losgebrand het:

"Maar de korporaal, die mij bescheid bracht, was nog geen honderd pas van mij weg, of ik hoorde een paar schoten vallen. Ik dacht dat het slachtbeesten waren die geschoten werden; maar dadelijk viel er weer enige, en wat moesten wij zien? De Engelschen waren binnen twee honderd schreden van ons op het bultje aan den kant van Bothaville - den kant waar de brandwacht juis vandaan gekomen was." ${ }^{30)}$

Om ongeveer $05 \mathrm{~h} 30,{ }^{31)}$ dit wil sê tien minute ná sonopkoms, is die oggendstilte oor Doornkraal verbreek deur 'n sarsie geweerskote. Die slag van Doornkraal het in alle erns begin.

\section{SLAG VAN DOORNKRAAL}

Die vernietigende vuur wat maj Lean se 5th Mounted Infantry op die kamp afgebring het, het onmiddellik pandemonium veroorsaak. 'n Golf van verskrikking het deur die laer getre ${ }^{311}$ en die meeste burgers se eerste reaksie was om paniekbevange met die eerste en beste perd op die vlug te slaan. ${ }^{32)}$ Onder die Britse kwelvuur wat steeds aangegroei het, was dit egter nie 'n maklike taak om die verskrikte perde aan te keer en op te saal nie. Selfs generaal De Wet moes te midde van die chaos wat om hom losgebars het, self "maar uitzien waar mijn paard was om het opgezadeld te krijgen." ${ }^{\text {"3) }}$ En terwyl Lean se voorhoede op die bult versterkings bygekry het om nog meer lood in die laer te pomp, moes sommige burgers hul saels agterlaat en "bloots" uitjaag. ${ }^{34)}$ Ofskoon De Wet tydens die opsaal van sy perd hierdie paniekbevange stormloop probeer stuit en trouens ' $n$ teenaanval beveel het ("Stormt den vijand!"), ${ }^{35)}$ was sy pogings tevergeefs. Die vlugtende burgers se gemoedstemming op hierdie kritiese tydstip word heel paslik deur De Wet in 'n kort maar kragtige sin opgesom: "De schrik was daar." ${ }^{36)}$ 


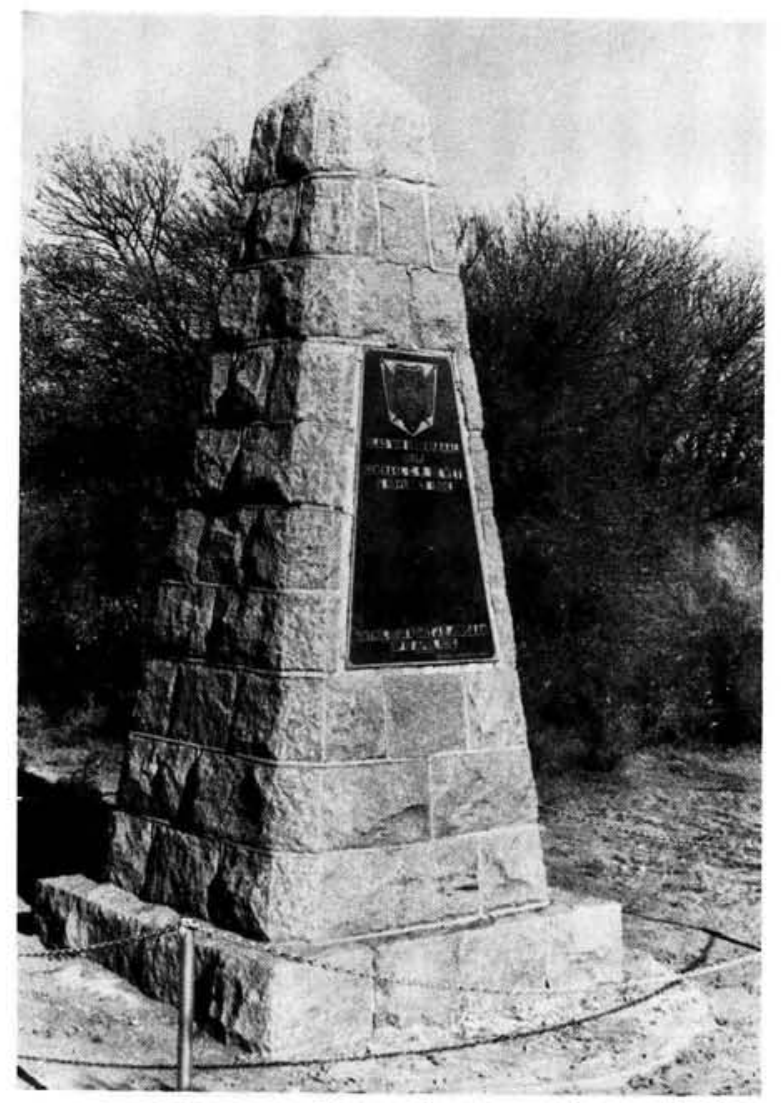

Hlerdle gedenksteen ter ere van generaal C.R. de Wet en dle Boerekrygers wat aan dle slag van Doornkraal deelgeneem het, is op 13 Aprll 1938 deur kmdt J.D. Jordaan onthul. Dle gedenksteen is teenaan die pad tussen Bothaville en Hoopstad (R 59) opgerig naby die plek vanwaar maj Kenneth Lean 'n verrassingsaanval op De Wet se staanplek geloods het

Intussen het die twee kanonne van U. Battery die gevegstoneel bereik en vanaf 'n posisie sowat 70 meter agter Lean se vuurlinie op die kamp begin vuur. ${ }^{37)}$ Dit het nog groter verwarring en paniek gewek sodat generaal De Wet oplaas self onder die vyandelike vuur moes uitjaag. Volgens De Wet was dit sy uitsluitlike doel om die vlugtende burgers te keer en terug te bring hoewel hy nie veel sukses daarmee gehad het nie:

"Voor mij viel niets te doen, dan te paard te springen en te trachten de burgers terug te brengen. Maar neen! ik kon het niet doen. Als ik de burgers op heet eene punt keerde, dan gingen anderen op een ander punt voorbij; totdat spoedig het geheele commando van onder het vuur uit was." ${ }^{38)}$

Die feit dat die grootste deel van die kommando's daarin kon slaag om onder die vyandelike vuur berede uit te vlug, was in sigself merkwaardig, al het hul optrede nie juis van dapperheid gespreek nie! En tog was daar dié ongelukkige minderheid van enkelinge wat in die woorde van De Wet "zich aan hunne paarden niet stoorden, maar vochten." ${ }^{39)}$ Wat De Wet egter nie vermeld nie, is dat baie van hierdie burgers noodge- dwonge moes veg omdat hulle nie perde kon vang om te ontvlug nie. Dit is ook die oorwoë mening van Maurice:

\begin{abstract}
"Those who could secure their horses made off with all speed, many bareback - De Wet and Steyn amongst them. There remained about 200 men, who, unable to find their mounts, took shelter in a square stone-walled kraal, behind two dams. ${ }^{\text {40) }}$
\end{abstract}

Te midde van hierdie stormloop na veiligheid was daar wel iemand wat hom oor die Vrystaatse president ontferm het. Die lofwaardige altruïsme en lojaliteit van pres Steyn se adjudant spreek duidelik uit die volgende mededeling van Thomas Pakenham:

"The one great blessing was the safety of the most precious thing entrusted to the Commando: the life of President Steyn. Steyn's Adjudant, Du Preez, had kept his horse, Scot, ready saddled and tied to a food wagon. Steyn galloped off, leaving Du Preez to give covering fire. Steyn lost nothing except his cuff-links (sic)." ${ }^{.41)}$

Die 5th Mounted Infantry van maj Lean en die grofgeskut van It Otter Barry het nie oor genoeg vuurkrag beskik om die agterblywende burgers in die blootgestelde laer vas te pen nie. Die meeste het skuiling gaan soek agter die stewige klipmuur van die tuin en die grondwal van die aangrensende dam terwyl 'n paar afgesit het na 'n plaashuis (die "wit huis") wat verder suid geleë was. Drie burgers het noodgedwonge hul toevlug tot ' $n$ varkhok gevaarlik naby die Britse vuurlyn geneem en letterlik in 'n dodelike kruisvuur beland. Hulle is egter goed deur die varkhok se klipmuur beskut en die vyand het eers in 'n laat stadium van die geveg van hul teenwoordigheid bewus geword.

Die stryd het in felheid toegeneem namate meer Boere vanagter die tuinmuur en die damwal begin terugskiet het. Die ruitery van Lean het van die aanvanklike chaos in die laer gebruik gemaak om verder in ' $n$ suidwestelike rigting te ontplooi, maar hulle het hulle nou teen ' $n$ dodelike teenvuur vasgeloop. Drie kompanies, $\mathrm{nl}$ die Royal Irish aan die linkerkant by ' $n$ kraal ${ }^{42)}$, die Worcestershires in die middel en die Buffs op die vooruitgeskowe regterflank het tot sowat 20 meter van die varkhok gevorder voordat hulle gestuit is.

Inmiddels het 'n afdeling van die Oxford Light Infantry onder kapt G.N. Colvile aan die linkerflank van die 5th Mounted Infantry suidwaarts beweeg in die rigting van die plaasopstal (die "rooi huis") en 'n klipkraal. ${ }^{43)}$ Kapt Colvile self het 


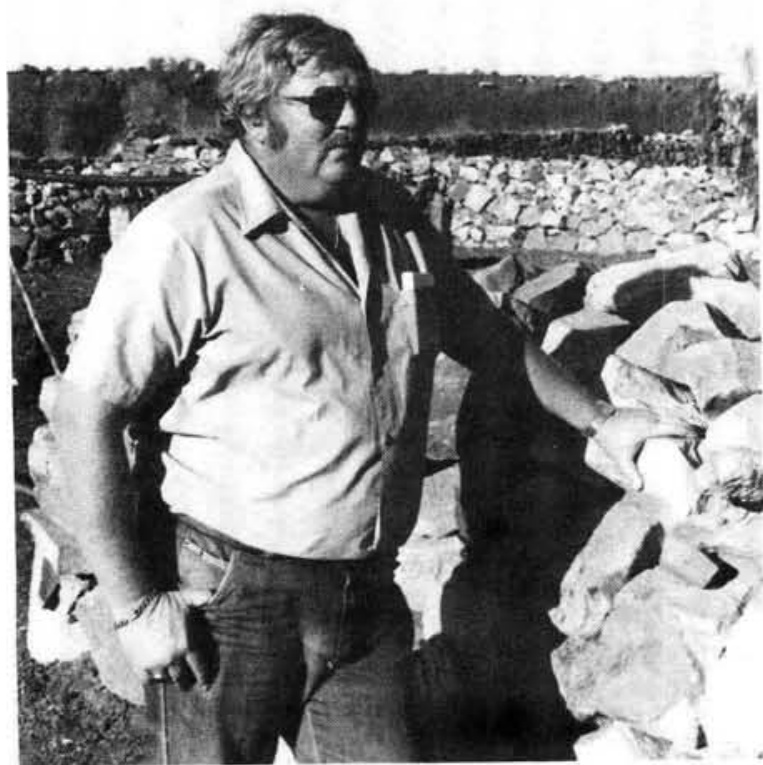

Mnr Hercules Odendaal by dle kllpkraal wat sedert dle slag van Doornkraal grootllks gehoue gebly het en nog steeds as veekraal gebruik word. Tydens die slag het dle Britse soldate wat onder kapt Colvile dle veekraal ingeneem het, bale vuur getrek en Colvile is gewond

die klipkraal in besit geneem terwyl It Percy Smith en 'n paar man die "rooi huis" beveilig het.

In hierdie stadium kon die 5th Mounted Infantry nog die verloop van die stryd dikteer veral danksy die oorhoofse dekking van U. Battery se twee kanonne op die bult. Die drie vasgekeerde burgers in die varkhok het ' $n$ goeie uitsig op hierdie stelling gehad en die artilleriste van It Otter Barry onder skoot gebring. Hierdie kanonne kon trouens nie na ' $n$ veiliger posisie verskuif word nie omdat die voorste trekperde reeds beswyk het. ${ }^{44)}$ 'n Paar Vrystaatse artilleriste het ook moedig probeer om drie kanonne in posisie te kry, maar hoewel hulle een hiervan in aksie gebring het, was dit van korte duur. Die Britse grofgeskut was reeds ingeskiet en met die kartetse en skrapnel wat om hulle gebars het, moes die Vrystaters hul kanonne los en skuiling soek. ${ }^{45}$ )

Op hierdie tydstip was die slag van Doornkraal nog in die weegskaal. Maj Lean se ruitery was nouliks in staat om die burgers agter die tuinmuur en damwal vas te pen, maar hy het reeds versterkings bygekry. Hierdie wending, wat die druk op die 5th Mounted Infantry enigsins verlig het, was te danke aan die verskyning van die voorste elemente van die 8th Mounted Infantry op die slagveld. Hieroor meld Amery die volgende:

"To the left of the 5th M.I. the Suffolk and West Riding de- tachments of the 8th M.I., under Captain Peebles and Lieutenant White, supported by another gun of " $U$ "-Battery under Captain Mair, now came up and worked round the right flank of the enemy, while 42 men of the 17th and 18th Companies of Yeomanry, under Captain Coates and Lieutenant Boulton, protected the right of the guns and were also warmly engaged. ${ }^{46)}$

Hierdie aankomelinge het gedurende hul kloksgewyse maneuver aan die suidoostelike kant van die slagveld egter vanuit ' $n$ onverwagte oord teenstand ondervind. Generaal De Wet se pleidooie was klaarblyklik nie heeltemal tevergeefs nie, want talle burgers was besig om na die gevegstoneel terug te keer. ' $n$ Groot aantal het aan die oostekant versamel en op die 5th Mounted Infantry se uitgestrekte linkerflank druk begin uitoefen. Hulle het nou ook slaags geraak met die naderende voorhoede van die 8th Mounted Infantry van kapt A.S. Peebles en die Yeomanry onder kapt Coates. Kort hierna is die kanon van U.Battery onder kapt Mair buite aksie gestel. ${ }^{47)}$

Terwyl hierdie verbete stryd aan die oostekant van die slagveld aan die gang was, het It kol Le Gallais sy opwagting gemaak. Hy het ná sy aankoms dadelik besef dat die Boere ' $n$ bedreiging vir sy linkerflank ingehou het en sy stafoffisier, maj W.B. Hickie, ${ }^{48)}$ na die heliograaf gestuur om die eskort van die leërtros onder maj N.C. Welch as versterking te ontbied. ${ }^{49)}$ Hierna het Le Gallais met sy stafoffisiere en 'n paar man die "rooi huis" vanaf die oostekant binnegegaan.

Lt kol Le Gallais se besluit om Christiaan van Wyk se plaasopstal as sy taktiese hoofkwartier in te rig, was waarskynlik daaraan toe te skryf dat dit ' $n$ sentrale punt op die slagveld was en ook 'n goeie uitsig op die Boere se verdedigingslinie agter die tuinmuur en die damwal gebied het. ${ }^{50)}$ Die huishoof en sy familielede is na die kombuis beveel waarna Le Gallais en sy staf hul begeef het na ' $n$ westelike venster wat op die tuin en dam uitgekyk het. ${ }^{51)}$ Dit was 'n onvergeeflike en fatale flater.

Die burgers agter die kort gedeelte van die tuinmuur aan die oostekant het insgelyks ' $n$ goeie uitsig op die huis gehad en hulle het gou bemerk wat gaande was. Die figure van die drie offisiere en hul manskappe was duidelik teen die oop deur agter hulle gesilhoeëteer en met dié maklike teikens in hul visiere, het die Boere op die huis se vensters losgebrand. 'n Dodelike fussillade het in 'n oogwink dood en verwoesting in die huis gesaai en soos Maurice tereg opmerk, 
"the house became a trap in which any movement brought instant death." ${ }^{\text {"2) }}$

Om $06 \mathrm{~h} 30$ het ' $n$ groot terugslag die Britse mag getref toe It kol Le Gallais deur 'n dodelike borswond neergevel is. Om sake te vererger, word die bevelvoerder van 8th Mounted Infantry, It kol W.C. Ross, kort hierna in die gesig getref en hy word met 'n verbryselde onderkaak na 'n veiliger plek in die huis gedra. ${ }^{53)}$ Dit was maar net die begin van ' $n$ makabere bloedblad wat reg aan die naam "rooi huis" laat geskied het; in die daaropvolgende twee ure word nog ses man raakgeskiet, oa kapt W.A.G. Williams, Ross se stafoffisier. Kapt Williams het kort ná die verwonding van It kol Ross aan veelvuldige koeëlwonde beswyk en in die afwesigheid van maj Hickie moes maj P.B. Taylor (bevelvoerder van U.Battery) die bevel oorneem. ${ }^{54)}$ van die res van die mag afgesny terwyl die kommando's nou ook die 5th Mounted Infantry se regterflank geteister het. Die aanmars van die 8th Mounted Infantry op die Britse linkerflank is gestuit en kwaai vuur is op die Britse soldate in die klipkraal afgebring. Hier is kapt Colvile gewond en sy plek is deur kapt Maurice ingeneem. Selfs die oostekant van die huis was nie meer veilig nie want kapt F.J. Englebach ${ }^{55}$ wat met 20 man van die Worcesters en die Royal Irish agter ' $n$ lae klipmuur geskuil het, is noodlottig gewond. ${ }^{56)}$ Lt Percy Smith, wat die "rooi huis" kort ná die aanvang van die geveg beset het, is ook gewond.

In die lig van hierdie kritieke situasie het maj Taylor besluit om weer eens versterkings aan te vra en 'n boodskapper afgestuur. Kort hierna het

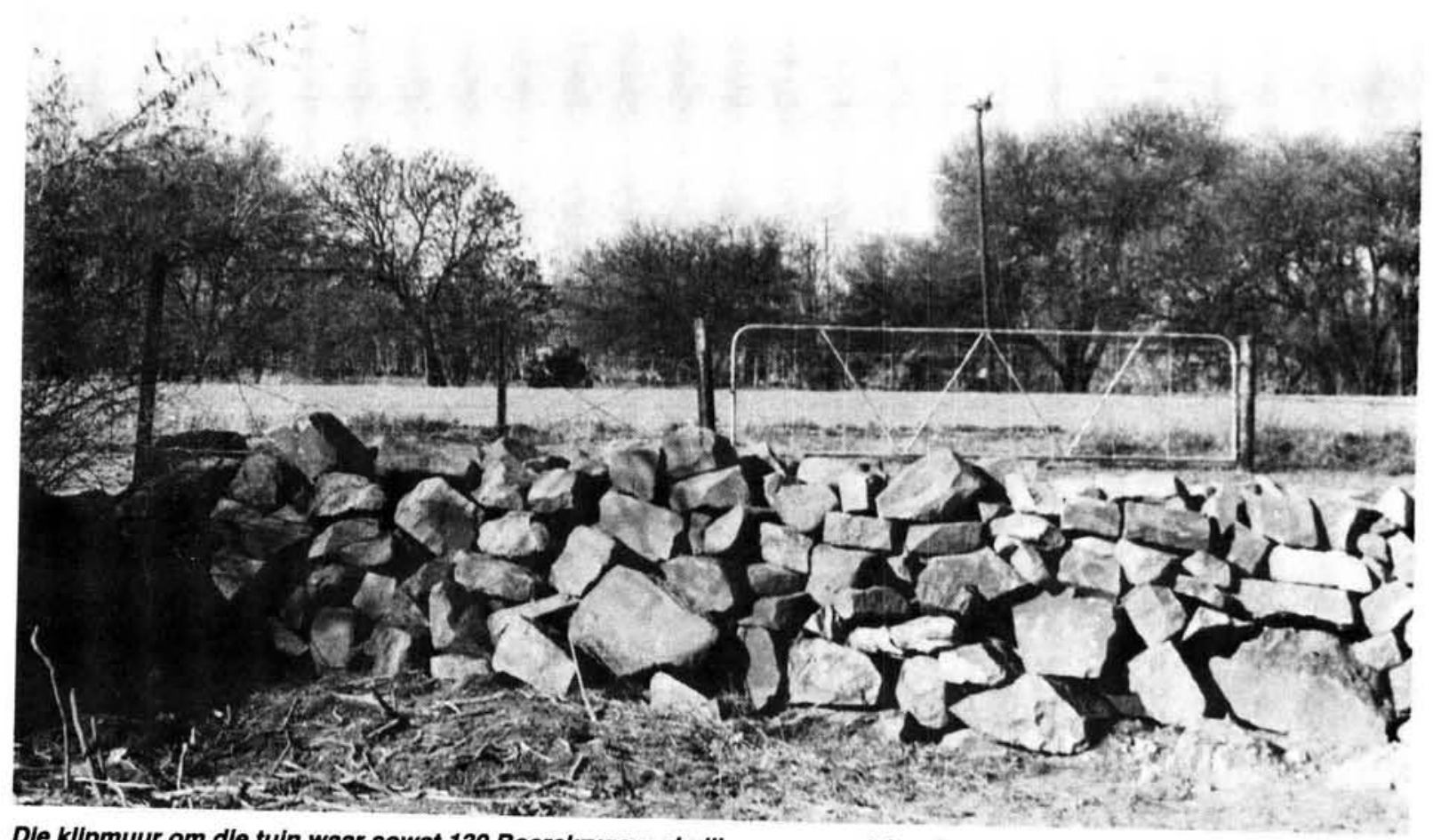

Die kllpmuur om dle tuin waar sowat 130 Boerekrygers skuiling gaan soek het, is goed bewaar. Die foto toon die posisle vanwaar It kol Le Gallals gesklet Is. Dle huldige plaaswoning oorkant dle grondpad word deur bome net regs van dle telefoonpaal verberg

Vir maj Taylor moes hierdie verantwoordelikheid 'n twyfelagtige eer gewees het want dit wou voorkom asof die Britse aanval besig was om in 'n fiasko te ontaard. As bevelvoerder was Taylor maj Hickie van die heliograaf teruggekeer en hyself het ternouerdood aan die dood ontkom toe sy perd digby die "rooi huis" onder hom doodgeskiet is. Hy het die deur egter veilig be- 


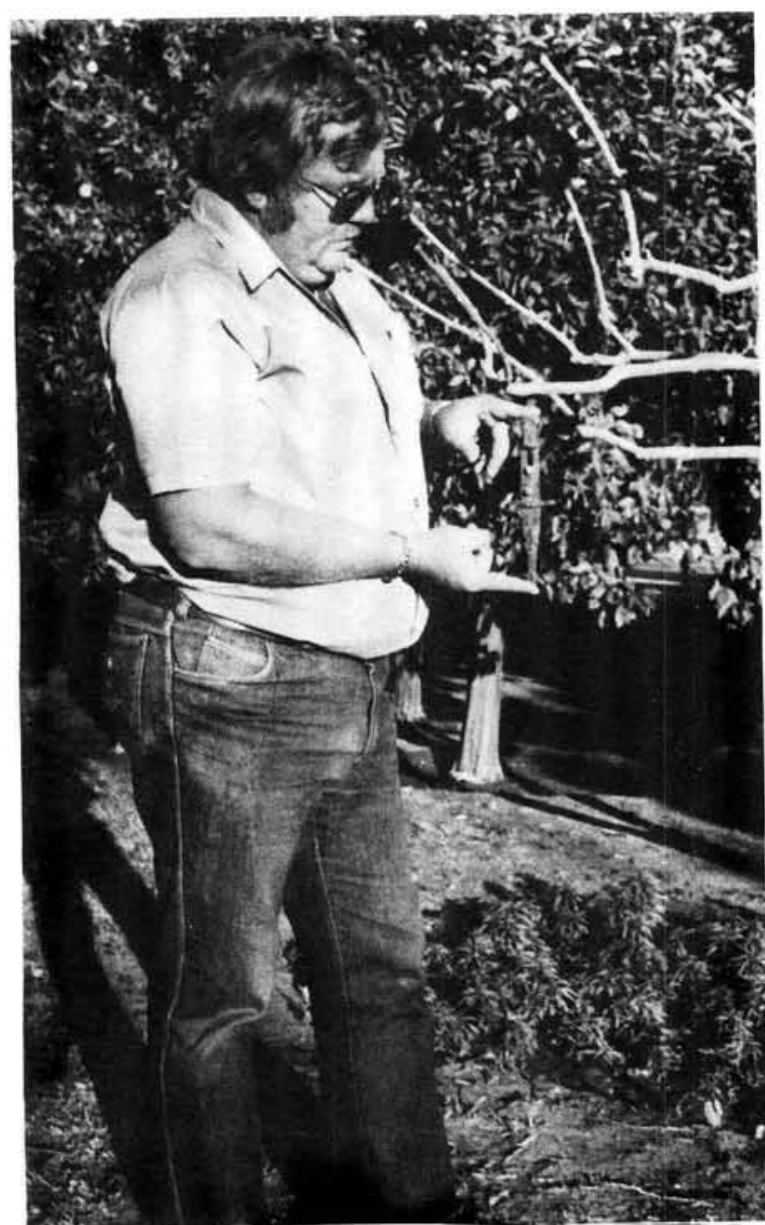

Mnr Hercules Odendaal, agterkleinseun van Christiaan van Wyk en eienaar van Klipkraal, toon hier 'n stuk van 'n Lee Enfield-bajonet wat hy onlangs aan die noordekant van die huis gevind het ongeveer waar ' $n$ twintigtal Britse soldate onder kapt Englebach deur die Boere se spervuur agter 'n lae klipmuur vasgepen was. Kapt Englebach is hier gedood

reik en in die huis by maj Taylor aangesluit. Oor Hickie se gewaarwordinge by die aanskoue van sy dooie en erg verminkte makkers, skryf Pakenham:

"He found the red farmhouse had become a butcher's shop. Through the open doorway, the Boers had picked off the officers: the chief himself, Le Gallais, with a ghastly wound in the body; Lieutenant-Colonel Wally Ross, the $\mathrm{CO}$ of the 8th MI, with the lower part of his jaw shot away: Major Williams, Ross's staff officer, with six bullets in him - altogether, eight men, with ghastly wounds. "57)

Die kommando's het inderdaad vrylik op die slagveld beweeg en was op die punt om die uitgestrekte Britse verdedigingslinie te oorrompel. Maar die Britse soldate het verbete teruggeveg terwyl die twee kanonne van Otter Barry op die bult die Boere in die tuin verhoed het om weg te breek. Boonop het die eerste Britse versterkings opgedaag. Hierdie wending word soos volg deur Amery beskryf: not a moment too soon, reinforcements began to arrive. Knox at his camp on Eland's Vlei, ten miles north of Bothaville, had heard overnight of Le Gallais's fight at the river, and at 5 a.m. had started south with De Lisle's column. Soon afterwards Le Gallais's guns were heard in action. De Lisle at once galloped forward at top speed, followed by every man who could hold the pace. At the drift close to Bothaville he received the message for help, and promptly forwarded assistance. $^{\text {.58) }}$

Die eerste versterkings wat opgedaag het, was egter 150 man van die 7th Mounted Infantry van Le Gallais wat die 8th Mounted Infantry op die linkerflank aangevul het. ${ }^{59)}$ Danksy hierdie versterkings wat om ongeveer $08 \mathrm{~h} 00$ opgedaag het, kon die Boere se teenoffensief afgeweer word. Die Britse grofgeskut het die kommando's steeds op ' $n$ afstand gehou en die burgers agter die tuinmuur verhoed om te onttrek. ${ }^{60)}$ Die Britse artillerie is verder versterk met die aankoms van 'n pom-pom op die linkerflank wat met die ondersteuning van die New South Wales Mounted Rifles ' $n$ aanslag op die "wit huis" gedoen het. ${ }^{61)}$ Dit het meegebring dat die Britse artillerie die slagveld in 'n hoë mate kon domineer ondanks die feit dat die bombardiers swaar verliese gely het. Aan heldemoed het dit ook nie ontbreek nie - sers Jackson meld in sy dagboek dat die Boere op 'n keer soveel vuur op die kanonne afgebring het dat die bemannings die wyk moes neem. Hy skryf:

"At one time the rifle-fire was so hot that our guns were left, but about eight M.I. crawled up and got under them, so they were never really abandoned. A man named Green, of the Lincolns, got the D.C.M. for carrying ammunition. He took a case along the firing line scarcely 100 yards from the position." 62 )

Om ongeveer $10 \mathrm{~h} 15$ het die kolonne van It kol De Lisle met die res van die 7th Mounted Infantry opgedaag en die kommando's het na die suide begin uitwyk. Volgens Amery is die oorblywende gedeelte van die 7th Mounted Infantry deur maj N.C. Welch ${ }^{63)}$ aangevoer en in hierdie verband verskaf sers Jackson ' $n$ interessante beskrywing van sy aankoms by Doornkraal:

"He was in charge of the convoy at the time, and on being sent for he came up at a comfortable hand-gallop, swinging his cane, and talking to himself, I've no doubt, as it was ' $n$ great habit of his. He was proceeding to inspect the position, when he was shot through the neck."64)

Met sy aankoms op Doornkraal, het It kol De Lisle hom gehaas na die "rooi huis" om met majore Taylor en Hickie te beraadslaag. Hierna het maj Welch opdrag gekry om met 'n saamgestelde mag van die 7 th/8th Mounted Infantry vanaf die Britse linkerflank oos van die klipkraal 'n kloksge- 
wyse omtrekbeweging uit te voer. Hierdeur sou die Boere in die tuin en agter die damwal omsingel en afgesluit word. Intussen het die 6th Mounted Infantry, die West Australian Mounted Infantry en afdelings van Kitchener's Horse bygekom en hulle is grotendeels oos en suid van die "rooi huis" ontplooi. Terwyl maj Welch met sy omtrekbeweging besig was, moes 'n kontingent van die West Australian Mounted Infantry onder It H.E. Darling ingestuur word om die verswakte linie van maj Lean se 5th Mounted Infantry op die bult te versterk. ${ }^{65)}$

Die Boere se posisie was benard en vir die sowat 130 burgers in die tuin en agter die damwal was daar geen uitkomkans nie. Nietemin het hulle nog verwoed teruggeveg en die Britse offisiere is veral as teikens uitgesoek. Gedurende die omtrekbeweging is maj Welch noodlotting gewond (soos reeds deur Jackson vermeld) terwyl kapt Peebles ook gewond is. Maar die burgers wat deur hul makkers by Doornkraal agtergelaat is, het self swaar verliese gely en dit was net 'n kwessie van tyd voordat hulle sou moes oorgee. Die einde van die slag van Doornkraal word soos volg deur Amery beskryf:

"De Lisle now realised that the time had come for a decisive assault. ... At De Lisle's orders Lean collected a storming party of the 5th M.I. and Darling's West Australians, and ordered a charge with the bayonet. But at the first flash of steel a white flag went fluttering up, and amid the shouts of the victors, the Boers held up their hands and surrendered." 66$)$

Volgens sers Jackson was hierdie laaste stormloop met gevelde bajonette nie so flambojant as sommige skrywers wil voorgee nie - slegs vier soldate kon met gevelde bajonette storm "as the majority had been used for picqueting pegs so often that the socket was knocked flat!"67

Eers toe die laaste skote oor Doornkraal weggesterf het, het die felheid van die gelewerde slag duidelik geword. 'n Rustige plaasmilieu moes plek maak vir die grusame nalatenis waaruit die bittere stryd tussen Boer en Brit ontnugterend tot die oorlewendes gespreek het: oral kon die versplinterende oorblyfsels van waens en perdekarre gesien word terwyl die dooie karkasse van perde verstrooid oor die slagveld gelê het. En dan was daar die dooies en gewondes wat oor ' $n$ uitgestrekte gebied in waens opgelaai en na die plaasopstal aangery moes word. By die varkhok het die Engelse soldate afgekom op twee van die burgers wat ure lank in ' $n$ dodelike kruisvuur vasgekeer was - een was reeds dood, die ander sterwend. Kort voor sy dood het hy aan die Engelse soldate wat hom na die plaashuis gedra het, vertel dat hy ' $n$ Transvaalse burger was wat die vorige dag by generaal De Wet se kommando aangesluit het. ${ }^{68)}$

Die gesneuwelde burgers is met dieselfde eerbied as hul Britse eweknieë ' $n$ ent van die "rooi huis" begrawe. Daar het 'n oomblik van erkentlikheid en wedersydse respek geheers, maar nadat die dooies ter ruste gelê is, was sommige Britse offisiere en soldate minder hoflik. In hierdie verband skryf Pakenham:

"After such an ordeal the British soldiers were in no mood for gallantry. In Hickie's words: 'Our men were all wild as nearly all our casualties were from explosive bullets' (contrary to the unsigned Hague convention). "69)

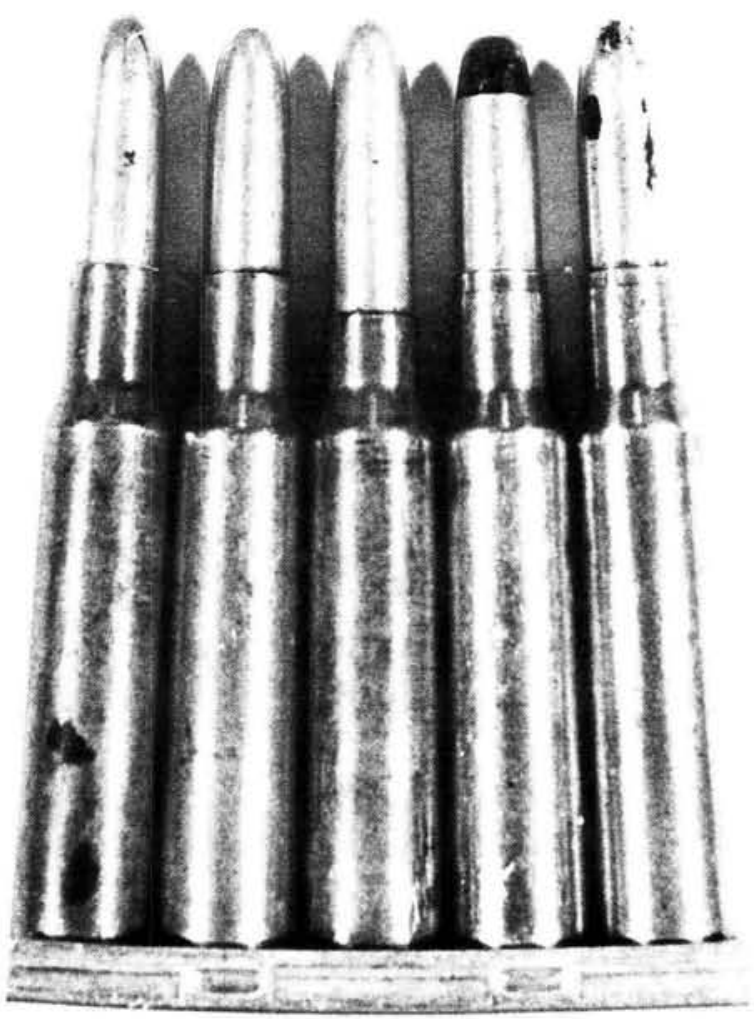

\begin{abstract}
Die sogenaamde 'Vyfie' met drie variasies van die $7 \mathrm{~mm}$ Mauserpatroon in ' $n$ klem wat die skutter in staat gestel het om vyf patrone gelyktydig in die magasyn te stoot. Die patroon tweede van regs het 'n ietwat platter loodpunt met ' $n$ nikkelmantel gehad wat ' $n$ groter wond as die ander veroorsaak het ofskoon dit nie naastenby met die $7,7 \mathrm{~mm}$ patrone van die Lee-Metford vergelyk kon word nie
\end{abstract}

Maj Hickie het die krygsgevangenes laat deursoek en by twee burgers is plofkoeëls ${ }^{70)}$ gevind. Meegesleur deur sy emosionele woede, het Hickie opdrag gegee dat die burgers binne 'n halfuur gefusileer moes word. Toe kol Knox hieroor ingelig is, het hy aanvanklik geen beswaar 
gehad nie maar later het hy hom bedink en beveel dat die twee burgers eers voor 'n krygsraad moes verskyn. Intussen het die gemoedere bedaar en het die Engelse nie meer kans gesien om die twee burgers koelbloedig dood te skiet nie. $^{71)}$

Maj Hickie se skerp aantuiging oor die beweerde gebruik van plofkoeëls deur die Boere verdien verdere toeligting. Sommige Britse offisiere en soldate (veral dié in die "rooi huis") het weliswaar lelike skietwonde opgedoen, maar wat beide Hickie en Pakenham verswyg, is die feit dat die $7 \mathrm{~mm}$ Mauserkoeël selde indien ooit 'n gapende skietwond kon veroorsaak. Dit versterk die vermoede dat die Boere in hierdie geval gebruik gemaak het van Lee-Metford-gewere en -ammunisie wat hulle by die Britse magte gebuit het. Toetse waarin die Mauser met die Lee-Metford vergelyk is, het aangetoon dat die $7 \mathrm{~mm}$ Mauserkoeël 'n kleiner skedelwond veroorsaak as die gewone $7,7 \mathrm{~mm}$ Lee-Metfordkoeël en die berugte $7,7 \mathrm{~mm}$ dum-dum-koeël wat vrylik deur die Britse magte gebruik is. Die plofkoeëls wat by die burgers gevind is, was waarskynlik die $7,7 \mathrm{~mm}$ (Mk IV) dum-dum wat in Indië vervaardig is vir die Lee-Metford. ${ }^{72)}$

Maj Hickie was eweneens baie krities oor die optrede van kol Knox ('that old woman') ${ }^{73)}$ en sy 'brilliant staff of red-tabbed officers, whose only interest in the battle seemed to concern the equitable disposal of De Wet's laager. ${ }^{174)}$ In hierdie verband is besluit dat die waens links van die pad deur It kol De Lisle se kolonne gebuit kon word terwyl dié regs van die pad aan Le Gallais se mag toegesê is. ${ }^{75)}$

Vir die oorwinnaars was daar meer as genoeg om te buit. Sekerlik die belangrikste deel hiervan was ' $n$ groot komplement van grofgeskut bestaande uit een 12-ponder (voorheen van Q.Battery, Royal Horse Artillery by Sannaspost gebuit); een 15-ponder (deur die Boere van 14 Battery, Royal Field Artillery by Colenso gebuit); drie $75 \mathrm{~mm}$ - en een eenponder-Krupps; en een Vickers-Maxim. Volgens Britse bronne is ' $n$ groot hoeveelheid ammunisie vir artillerie- en kleingeweerwapens gebuit ${ }^{76)}$, dog De Wet beweer dat die 'ammunitie voor deze stukken bijna uitgeput was $^{177)}$.

Benewens hierdie wapentuig en ammunisie, is ook ' $n$ groot aantal perde, perdekarre en waens gebuit. Die kommando's het heelwat van hul persoonlike besittings soos klere en perdesaels verloor, maar hul grootste verlies was die burgers wat gesneuwel het of krygsgevange geneem is. Hieroor meld De Wet die volgende:

'Ons verlies was zoo ver ik uitvinden kon negen dood, tusschen vijfentwintig en derdig gewond en ongeveer honderd krijgsgevangenen. Onder de gedooden waren de Veldcornetten Jan Viljoen van Heilbron, en Van Zijl van de Kaapkolonie; en onder de gewonden Staatsprocureur Jacob de Villiers en Jan Rechter, die later overleed. Onder de gekwesten, die er in slaagden uit te jagen, was Gen. Froneman, die licht in de borst gewond werd, de heer Tom. Brain, licht in de dij, één van mijn staf zwaar, maar niet doodelijk door den schouder, en eenige anderen, wier namen ik mij niet herinneren kan. ${ }^{78)}$

Volgens Maurice het 25 burgers gesneuwel, terwyl 130 krygsgevange geneem is van wie dertig gewond was. ${ }^{79)}$ Amery beweer dat 17 burgers omgekom het en 114 krygsgevange geneem is, insluitende 17 gewondes ${ }^{80)}$ Maurice stel Britse verliese op 13 gedood insluitende 3 offisiere (sic) en 25 gewond. ${ }^{81)}$ Volgens Amery het Britse ongevalle (gedood of gewond) 10 offisiere ingesluit wat ' $n$ goeie aanduiding is van die mate waartoe die Britse bevelselement as teikens uitgesoek is ${ }^{82)}$ Altesaam 4 Britse offisiere het by Doornkraal gesneuwel. ${ }^{83)}$

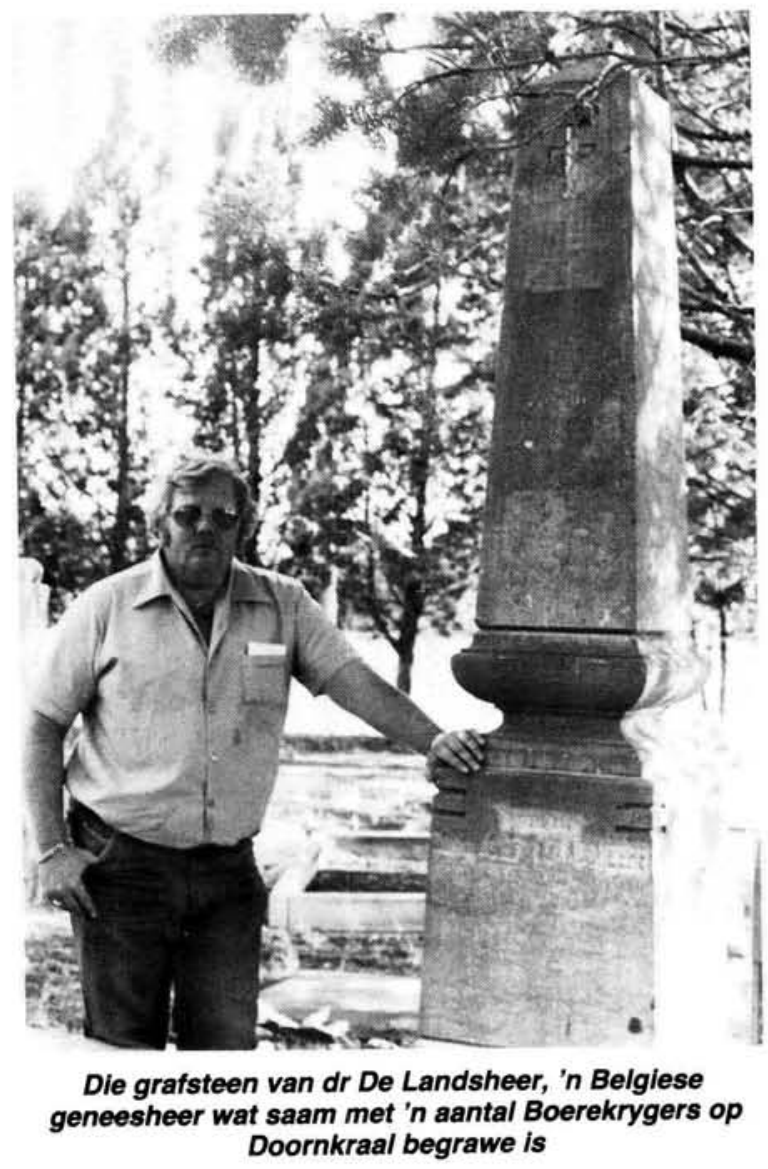

Die oorlye van die Belgiese geneesheer wat die kommando's vergesel het, dr De Landsheer, 
word ook deur De Wet genoem. Britse koerante het later aangevoer dat die Belgiese dokter met 'n patroonband om sy lyf gevind is met die implikasie dat hy wederregtelik aan die stryd deelgeneem het. Dit word egter prontuit as valse propaganda deur De Wet afgemaak. ${ }^{84)}$

Om 20 h30 daardie aand het It kol Le Gallais aan sy wond beswyk. In sy laaste lewensoomblikke sou hy die volgende gesê het: 'Tell my mother that I died happy, as we got the guns. ${ }^{\left.{ }^{85}\right)}$ In sy boek betuig generaal De Wet hulde aan hierdie voortreflike aanvoerder: 'Hij was, zonder twijfel, een van de dapperste aanvoerders der Engelschen, dien ik gezien heb. ${ }^{86)}$ Die dood van Le Gallais is as ' $n$ groot verlies en terugslag beskou en veldmaarskalk Roberts het in ' $n$ verslag na hom verwys as 'a most gallant and capable leader, whose place it will be very difficult to fill. ${ }^{87)}$ In 'n latere verslag ook die volgende oor Le Gallais geskryf: 'He rendered brilliant service and gave every promise of rising to the highest rank as cavalry leader. ${ }^{188)}$

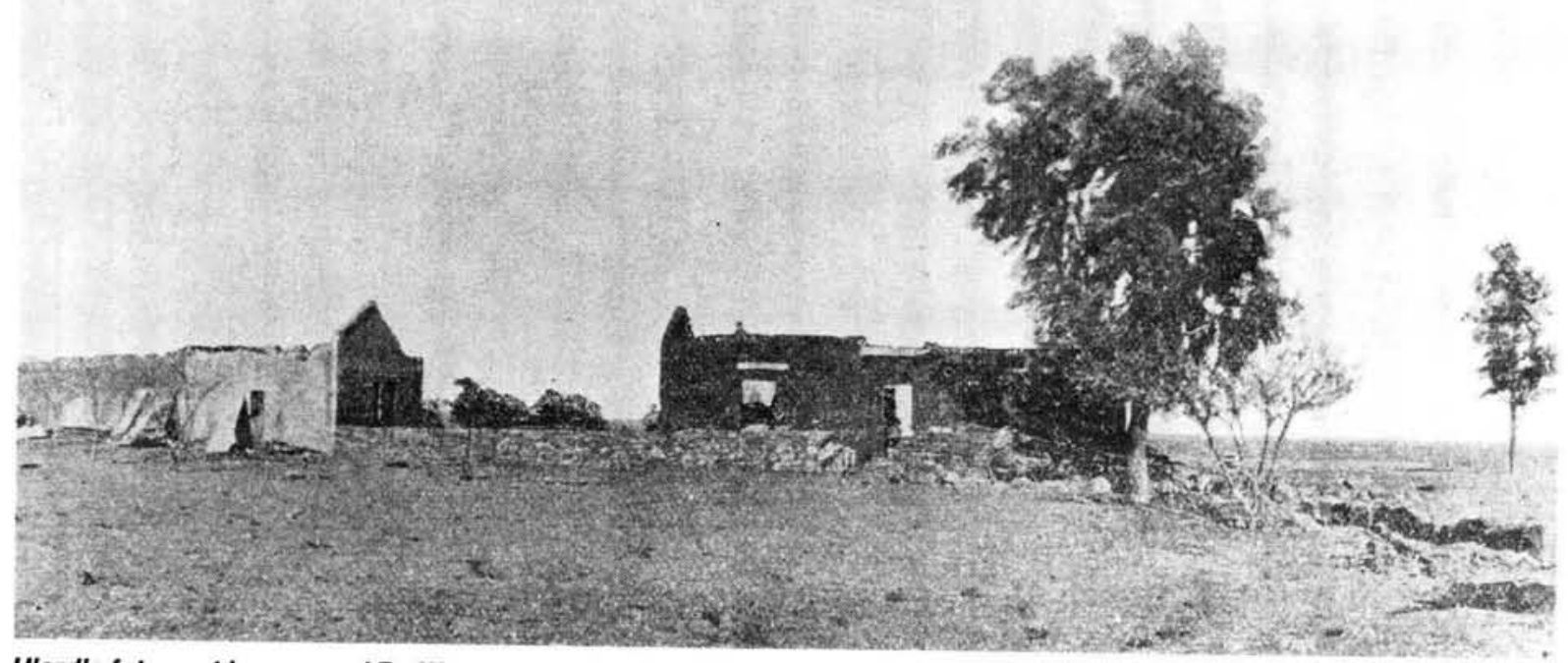

Hierdle foto, wat in generaal De Wet se boek De Strijd tusschen Boer en Brit opgeneem is, toon hoe die opstal op Doornkraal (waar It kol Le Gallals aan 'n koeel/wond beswyk het) soos dit daar uitgesien het nadat dit deur Britse soldate afgebrand is. Die foto is vanaf dle oostekant geneem

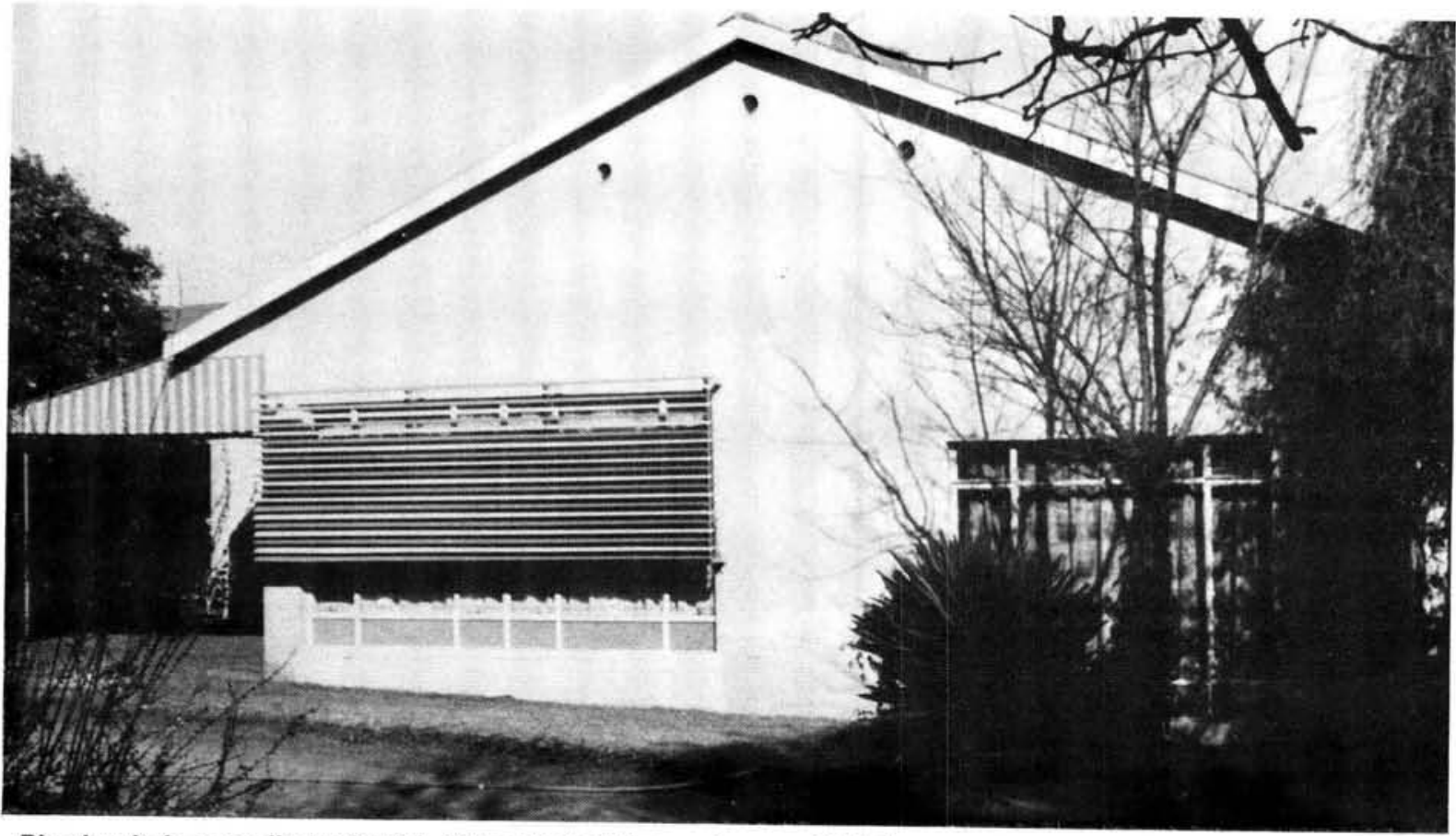

Dle plaashuls soos dit vandag lyk. Die oorspronkllke woning van Christiaan van Wyk is grootliks herbou ofskoon die spltsvormige dakpatroon bewaar gebly het. Die foto toon die suidelike syaansig 
Die Britse magte het 'n duur prys vir hul oorwinning by Doornkraal betaal en die dood van soveel offisiere het waarskynlik daartoe bygedra dat ' $n$ halfhartige poging aangewend is om die vlugtende kommando's te agtervolg. Hiermee is nie veel welslae behaal nie omdat die kommando's in klein groepies verdeel het waardeur hulle vinniger na die suide kon uitvlug. Die Britse mag van kol Knox het ook gefaal in sy vernaamste oogmerk, nl om Steyn en De Wet vas te keer en tot oorgawe te dwing. En saam met hulle het nog twee generaals, $\mathrm{nl}$ C.C. Froneman en P.S. Steenekamp daarin geslaag om te ontsnap. Al hierdie generaals het tot aan die einde van die oorlog in die veld gebly en waar en wanneer die geleentheid hom voorgedoen het, die vyand gevoelige verliese toegedien. Oor Doornkraal het De Wet wraak gesweer wat dan ook gestalte gevind het in die inname van Dewetsdorp op 23 November $1900 .^{89)}$

\section{EPILOOG}

Christiaan van Wyk en sy gesin het nog enkele maande ná die slag van Doornkraal op die plaas aangebly, maar Kitchener se beleid van 'verskroeide aarde' het die gesin op die ou einde gedwing om te vlug. Nege maande ná die slag van Doornkraal is die huis deur ' $n$ koloniale afdeling van die Britse magte afgebrand. 'n Interessante staaltjie oor Doornkraal - toe reeds verlate - word deur J.F.C. Fuller in sy oorlogsjoernaal gegee:

'On Sundays, Thomas, or Thompson (I am not certain of his name), the padre, used to come over from Kroomdraai and hold a service, and I remember on one of these occasions he said to me: 'I should much like to visit Le Gallais's farm' - this was Doornkraal, where Colonel Le Gallais had been killed. 'It is safe to ride out there?'
'Oh! yes,' I answered, 'there isn't a Boer near the place, but I will send out a couple of scouts with you.

So out they rode, and they had not been gone long when I heard a shot or two fired, and imagined that they had put up some buck. Then back they came. Thomas leading, at a furious gallop.

What had happened? Thomas, minus his cap, told me. They had got within five hundred yards of the farm when they were fired on and had then bolted back. Did the scouts return the fire? Not exactly, but one of them, a Kaffir named Long Boy, had turned round during the retreat holding his rifle in the air and had pulled the trigger - that was all.

Expressing my regrets to Thomas, I suggested his returning, saying that I would go out with my commando as his escort. 'No,' he answered, 'I don't think so. That would not be fair on my wife!"90)

Ná die oorlog is die verwoeste plaasopstal herstel en van 'n nuwe dak voorsien. Die 'wit huis', waar 'n paar burgers gedurende die geveg gedood is, het later egter in onbruik verval en is gesloop. Die oorspronklike plaas is in latere jare onderverdeel in kleiner plase sodat die slagveld vandag oor verskillend plase versprei lê, onder meer Klipkraal (waar die herboude plaasopstal van Christiaan van Wyk en die klipkraal geleë is), Holvley (waar De Wet se laer was), Gelykvlakte en Middelplaats. Die klipmuur van die tuin en 'n gedeelte van die aanliggende gronddam se wal het behoue gebly terwyl die klipkraal soos destyds steeds as veekraal gebruik word. Die oorspronklike krygsakker waar Brit en Boer is naasliggende grafte hul laaste rusplek gevind het, sou later deel word van 'n familiekerkhof. In die laat sestigerjare is die reste van It kol Le Gallais en sy makkers egter opgegrawe en in ' $n$ spesiale krygsakker op Bothaville herbegrawe.

*Kmdt C.J. Nöthling, MA, is verbonde aan die Militêre Informasieburo van die SAW.

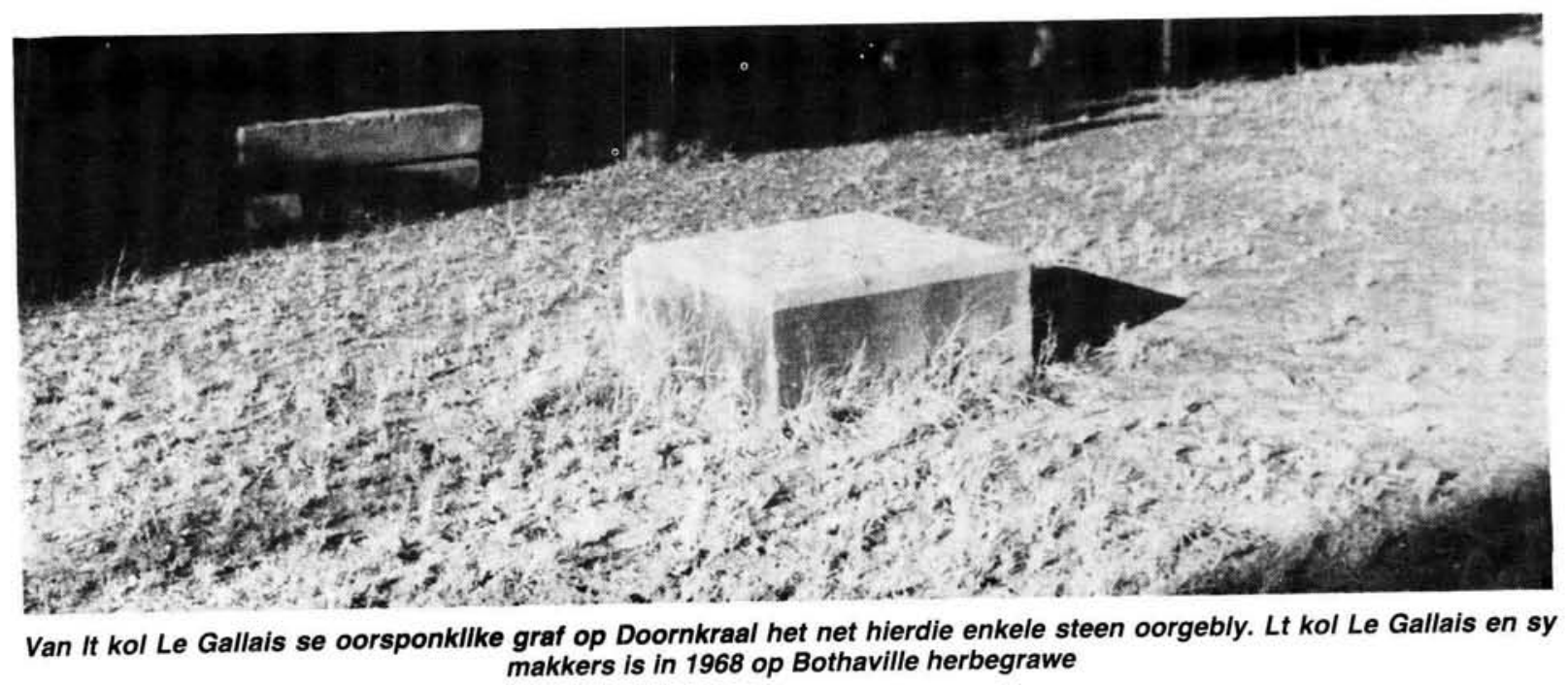




\section{Verwysings}

(1) Van Schoor, M.C.E.: De Wet, S.A.U.K., Johannesburg s.j., p 8. In hierdie verband skryf Van Schoor: 'Genl De Wet het by herhaling beweer dat sy sukses op die slagveld uitsluitlik aan die werk van sy verkenners toegeskryf moet word.'

(2) Rabie, J.E.: Generaal C.R. de Wet se krygsieiding by Sannaspos en Groenkop, Dokumentasiediens (SAW), Pretoria 1980, p 21.

(3) De Wet, C.R.: De strijd tusschen Boer en Brit, Boekhandel, Amsterdam/ Pretoria 1902, p 224. De Wet meld dat hy by dié geleentheid 'gewone burgers' as verkenners gebruik het wat hom kort voor die Britse aanval teen die naderende vyand gewaarsku het.

(4) Ofskoon De Wet reeds in Maart 1900 sy eerste noemenswaardige guerilla-operasie onderneem het, is sy kommando se beweeglikheid hierna steeds aan bande gelê deur 'n gevolg van ossewaens en kanonne. By Doornkraal was meer as 800 burgers onder sy bevel saamgetrek.

(5) De Wet, C.R.: op cit, p 224

(6) Krüger, D.W., en C.J. Beyers: Dictionary of South African Biography (Vol 3), Tafelberg, Pretoria 1977, pp 472-473. Kol Knox se veldslae by Rensburgdrift en Doornkraal was sy enigste oorwinnings oor generaal De Wet. Gedurende die oorlog het hy verskeie dryfjagte teen De Wet aangevoer, dog sonder sukses. Hy is in 1902 tot generaal-majoor bevorder en het met die rang luitenant-generaal uit die diens getree. Sir Charles Edmond Knox is op 1 November 1938 in die ouderdom van 91 jaar oorlede.

(7) Dooner, M.G.: The Last Post (e.v.), Simpkin \& Marshall, Londen s.j., p 214. Die volgende biografiese gegewens word verskaf: 'Lieut.-Col. Philip Walter Jules Le Gallais, 8th Hussars .... was born Aug., 1861. educated at Victoria College, Jersey, and entered the 8th Hussars from the 3rd or South Regt. (Royal Jersey Militia), April 1881, being promoted lieut. July the same year, capt. March, 1888, major April, 1897, and brevet lieut.-col. Nov., 1898. He served in the Nile Expedition of 1898, when he took part in the cavalry reconnaissance of April 4th, and the battles of Atbara and Khartoum. He was mentioned in despatches, L.G., May 24th and Sept. 30th, 1898, and received the brevet of lieut.col., Fourth Class of the Order of the Osmanieh, and two clasps to his Egyptian medal.' (Gedurende die Tweede Vryheidsoorlog neem hy as brigadebevelvoerder met 101 offisiere en 1851 manskappe onder sy bevel deel aan die besetting van Bloemfontein op 13 Maart 1900. Lt kol Le Gallais lewer ook aktiewe diens in operasies by oa Driefontein en die Waterwerke naby Bloemfontein op 29 Maart 1900 . Onder genl maj B.M. Hamilton neem hy in September 1900 deel aan die ontsetting van Ladybrand en hy is ook betrokke by die besetting van Frankfort op 3 Oktober 1900 en Bothaville op 20 Oktober 1900.)

(8) The Official Army List for the Quarter ending 29th June, 1895, (British) War Office, Londen Julie 1895, p 1366. Die volgende word vermeld: 'De Lisle, H. de B. (Capt. Durh. L.I.) - Soudan, 1885 - 6. - Frontier Field Force. Employed with Mounted Infantry. Attack on Ambigole Wells, action at Giniss and pursuit to Absarat. Mentioned in Despatches. Medal: DSO.' (In die Tweede Vryheidsoorlog neem hy deel aan die opmars vanaf Bloemfontein na Kroonstad en is later betrokke by die oorgawe van Pretoria in Junie 1900 . Hy neem deel aan die slag van Donkerhoek in dieselfde maand en onderneem operasies teen generaal De Wet in Augustus 1900. Hy speel ook 'n belangrike rol tydens die slag van Paardeberg en het ' $n$ aandeel aan die Britse offensief by Poplar Grove in Maart 1900 en die slag van Houtnek op 30 April 1900.

(9) Maurice, F., et al: History of the War in South Africa 1899-1902 (Vol 3), Hurst \& Blackett, Londen 1908, pp 483-484.

(10) Maurice, F., Ibid, p 528. Hiervolgens is 2nd Corps Mounted Infantry van kapt (plaaslike rang It kol) H. de B. Lisle (Durham Light Infantry) ingedeel by 1 st Brigade van kol (plaaslike rang genl maj) E.T.H. Hutton. Hierdie brigade het deel gevorm van die Mounted Infantry Division (Orange Free State) met kol (plaaslike rang genl maj) I.S.M. Hamilton as
divisiebevelvoerder.

(11) Amery, L.S. (red), et al: The Times History of the War in South Africa 1899-1902 ( Vol 5), Sampson Low \& Marston, Londen 1907, p 14.

(12) De Wet, C.R.: op cit, p 226.

(13) Ibid.

(14) De Kock, W.J., D.W. Krüger et al: Suid-Afrikaanse Biografiese Woordeboek (Deel 2), Tafelberg, Kaapstad 1972, p 730. Ná hierdie afskeid het pres Kruger na Mosambiek vertrek waarvandaan hy na Europa gereis
het.

(15) Maurice, F.; et al: op cit, pp 484-485. Onder die indruk dat generaal De Wet in 'n noordoostelike rigting langs die suidelike oewer van die Vaalrivier uitgevlug het, het Knox op 28 Oktober 1900 na Viljoensdrift opgeruk, maar die slegte toestand van die paaie het hom van sy plan laat afsien. Die volgende dag het hy na Vredefort Road teruggekeer en sy magte oor 'n wye gebied tussen Rensburgdrift en Roodewal ontplooi. Op 31 Oktober is dié magte verder in 'n suidelike rigting ontplooi langs die spoorlyn met die berede infanterie van Le Gallais op die mees suidelike flank naby Honingspruit. Vanaf die spoorlyn is nou weswaarts geveeg en die gebied om Rhebokfontein omsingel, dog op 2 November het dit duidelik geword dat De Wet spoorloos verdwyn het (op daardie tydstip was De Wet nog by Ventersdorp en sy kommando in die omgewing van Bothaville).

(16) De Kock, W.J., D.W. Krüger et al: op cit, p 730.

(17) De Wet, C.R.: op cit, p 226.

(18) Ibid. (Generaal C.C. Froneman was een van die bekwaamste generaals wat De Wet onder sy bevel gehad het. Afgesien van 'n taktiese fout wat hy tydens generaal J.D.P. French se opmars na Kimberley in Februarie 1900 begaan het, onderskei hy hom as 'n bevelvoerder met goeie oordeel en vernuf; tydens generaal Cronjé se oorgawe by Paardeberg breek Froneman deur die Britse kordon en sluit by generaal De Wet aan. Vanaf Maart 1900 word De Wet en Froneman 'n gedugte kombinasie wat 'n deurslaggewende rol speel in die Britse nederlaag by Sannaspos. Gedurende die omsingeling en oorgawe van generaal Marthinus Prinsloo in Julie 1900 in die Brandwaterkom ontsnap hy om die guerillastryd in die Vrystaat voort te sit. Hy is ook teenwoordig by die slag van Rensburgdrift en Doornkraal en in 1901 bly hy aktief in die stryd. Net soos De Wet word hy in die laaste jaar van die oorlog as 'n gesogte teiken vir die Britse dryfjagte uitgesonder, maar hy slaag daarin om sy agtervolgers te ontwyk. Christoffel Cornelius Froneman is op 12 Maart 1913 in die distrik Senekal in die ouderdom van 66 jaar oorlede.)

(19) Maurice, F., et al: op cit, pp 484-485. Die skrywers vermeld verkeerdelik dat Le Gallais teen $12 \mathrm{~h} 00$ middag ongeveer 5 myl wes (lees: 00s) van die dorp was. Die Valschrivier se vloei was suid van die dorp verby eerder as deur Bothaville en die huise wat deur die voorhoede op die regteroewer gewaar is, het in werklikheid die woongebied se suidelike begrensing uitgemaak. Die posisie van die drif was waarskynlik wes van die ou brug wat eers later opgerig is - geleë en nie waar die brug vandag oor die rivier span nie. Dit dien vermeld te word dat genl maj J.F.C. Fuller in sy werk The Last of the Gentlemen's Wars (Faber \& Faber, Londen 1937) die posisie van die drif as wes van die dorp en net regs van die Valschrivier se suidwaartse kromming aandui (kaart). In hierdie verband verskaf hy die volgende topografiese gegewens: 'South of the drift the ground rose sharply. There was an easily defensible kopje with a fine field of fire to the south and west of it ... East of this kopje the ground first fell and then rose, and in this dip I installed my scouts, their horses and the quite extensive flock of sheep' ( $p 238$ ). Omdat Bothaville in die verlede deur die Boeremagte as ' $n$ basis gebruik is vir hul aanvalle op die spoorlyn, het It genl Hunter besluit om die woonhuise aldaar te vernietig. Le Gallais met meer as 1000 man onder sy bevel het deel uitgemaak van Hunter se mag wat op 20 Oktober 1900 die dorp beset en sowat 50 huise vernietig het. Sers Murray Cosby Jackson (7th Mounted Intantry), wat die aankoms van Le Gallais op 5 November 1900 in Bothaville meegemaak het, skryt in sy dagboek ( $A$ Soldier's Diary, South Africa 1899-1901, Max Goschen, Londen 1913) dat die Britse soldate op die vooraand van die slag van Doornkraal min geslaap het: 'No one slept much that night among the men, as we were all marching around the little town (which we had burnt) seeing what we could find. After everything was fixed up I went with my two mess-mates on a tour of inspection; this was about 11 p.m. The Lancers who burnt the place had pretty well gutted it, but we found a huge sow which had taken up its residence in the bank! We murdered her with a very small pen-knife and proceeded to fresh fields. I struck a good house standing in its own ground, that had not been touched for some reason. The veranda was full of boxes of crockery and small furniture, so I thought there might be something (eatable) inside, and was forcing a window in the most approved Sykes style when I heard a scuffle and a lot of swearing inside, and just as I cleared got a glimpse of several pyjama'd figures coming out of all the doors. The place must have been full of officers. I had no luck after that, so turned in about 2 a.m. in the main street' (pp 149-150).

(20) De Wet, C.R.: op cit, p 226.

(21) Ibid. Volgens De Wet is hierdie brandwag 'dicht bij de rivier' geplaas terwyl Maurice hul posisie op 2 myl $(3,2 \mathrm{~km})$ vanat die rivier stel. Dit word deur Amery bevestig. De Wet gee nie 'n aanduiding van hierdie waarskuwingspos se getalsterkte nie, dog Maurice en Amery meld dat 5 burgers gevang is.

(22) The Quarterly Army List for the Period ending 31st December 1914 Keliher \& Co, Londen 1915, p 2598. Sy diensrekord word soos volg aangegee: 'S. African War, 1879-81. - Zulu Campaign, and at the attack and capture of Sekukuni's town, and storming of the Fighting Koppie. Medal with clasp. Transvaal Campaign. - Siege of Potchefstroom ... Burmese Expedition, 1885-6. - Medal with clasp ... S. African War, 1899-1902. - Spec. Serv. Offr. (including employment under Censor from 14 Feb 00 , and in Comd. of 5 th $\mathrm{Bn}$. Mtd. Inf. (5th Corps Mtd. Inf. 29 Apr. to 26 May 00), 28 Mar. to 29 Nov. 00. Advance on Kimberley, including actions at Belmont, Enslin, Modder River and Magersfontein. Operations in the Orange Free State Feb. to May 00, 
including actions at Houtnek (Thaba Mountain), Vet River (5 and 6 May) and Zand River. Operations in the Transvaal in May and Jun. 00 including actions near Johannesburg, Pretoria and Diamond Hill (11 and 12 Jun.) Operations in the Transvaal, west of Pretoria, July to 29 Nov. 00. Operations in Orange River Colony (May to 29 Nov. 00) including actions at Wittebergen (1 to 29 July), Ladybrand (2 to 5 Sept), Bothaville, Caledon River (27 to 29 Nov.). In Commd. 5 Bn. Mtd. Inf., 30 Nov 00 to 30 Jun. 01, and in Commd. of a Mobile Column, 1 July 01 to 15 Mar. 02. Operations in Orange River Colony, Transvaal and Cape Colony, 30 Nov. to Mar. 02. Despatches, Lond. Gaz., 10 Sept. 01. Brev. of Lt.-Col. Queen's medal with 5 clasps. King's medal with 2 clasps.' (Kenneth E. Lean, wat op 28 Mei 1859 gebore is, het later as stafoffisier in Indië gedien; op 28 April 1912 is hy tot tydelike brigadiergeneraal bevorder en aangestel as Inspector of Volunteers (India). Op 1 April 1915 het hy dié rang behou met sy aanstelling as brigadegeneraal.

(23) Maurice, F., et al: op cit, p 486. 'Leërtros' (Eng: 'Baggage'): voorrade, proviand en ander logistiek. Die eskort hiervan onder maj Welch is gedurende die geveg per heliograaf na Doornkraal ontbied.

(24) Amery, L.S., et al: op cit, $p 16$.

(25) De Wet, C.R.: op cit, pp 226-227

(26) Amery, L.S., et al: op cit, $p 16$

(27) Maurice, F., et al: op cit, p 486

(28) Doyle, Arthur C.: The Great Boer War (Vol 1), Struik, Kaapstad 1976 (herdruk), p 531. Met die aanvang van die geveg het maj Lean sowat 67 man tot sy beskikking gehad en nie 40 soos Doyle beweer nie. Die werklike sterkte van die kommando's was ongeveer 800 , dws 200 minder as Doyle se raming.

(29) Jackson, Murray C.: A Soldier's Diary, South Africa 1899-1901, Max Goschen, Londen 1913, p 151. Die skrywer het as 'n sersant in die 7th Mounted Infantry gedien.

(30) De Wet, C.R.: op cit, p 227

(31) Amery, L.S., et al: op cit, p 16. Indien De Wet se berekende tyd van aanval ('De zon was geen twintig minuten opgegaan') aanvaar word, beteken dit dat die aanval om $05 \mathrm{~h} 40$ begin het. Die verskil van 10 minute kan moontlik verklaar word deur die feit dat die periode van eerstelig direk voor sonopkoms 10 minute geduur het.

(32) Pakenham, Thomas: The Boer War, Macdonald \& Kie, Londen 1982, p 474. Die skrywer se relaas oor die aanval op die laer en die kommando se uitvlug is grootliks op dié van De Wet gebaseer.

(33) De Wet, C.R.: op cit, p 228.

(34) Ibid.

(35) Ibid.

(36) Ibid.

(37) Maurice, F. et al: op cit, p 486. Hierdie twee kanonne was onder die bevel van It Otter Barry. Volgens L.S. Amery et al (p 16) is die voorste trekperde neergeskiet toe die kanonne die bult bereik het.

(38) De Wet, C.R.: op cit, p 228.

(39) Ibid.

(40) Maurice, F., et al: op cit, p 487

(41) Pakenham, Thomas: op cit, p 475. Pakenham se bewering oor pres Steyn se verlies ('cuff-links') is gebaseer op sir Alfred Milner se oorlogsdagboek (M's diary 31 Dec 1900) en moet gesien word in die geestesklimaat waarin dit geskryt is. Pres Steyn het waarskynlik baie meer verloor as sy mansjetknope (oa sy Kaapse kapkar) ofskoon sy vertrek met groter waardigheid geskied het as wat 'n skrywer soos Robert Hall (The South African Campaign, John K. Milne, Aberdeen 1901, p 273) wil voorgee: "He only escaped without his boots and in his shirt sleeves' (sic).

(42) Maurice, F., et al: op cit, p 486. Hierdie kraal word nie op Amery se kaart aangedui nie en die skrywer kon nie vasstel of dit verwys na die klipkraal nie (vide verwysing 43).

(43) Amery, L.S., et al: op cit, p 17. Die klipkraal het uit verskillende kompartemente bestaan waarvan die gestapelde klipmure besonder stewig was. Volgens wyle mnr Hercules van Wyk, 'n seun van Christiaan van Wyk (destydse eienaar van Doornkraal), was hy en twee van sy broers in die klipkraal besig om koeie te melk toe die eerste Britse soldate daar opgedaag het.

(44) Amery, L.S., Ibid.

(45) Maurice, F., et al: op cit, p 487.

(46) Amery, L.S., et al: op cit, $p 17$.

(47) Ibid, p 18. Danksy die hardnekkige weerstand van kapt Peebles en die Suffolk Mounted Infantry is die Boere verhoed om hierdie kanon te buit.

(48) Ibid, p 17. Die volgende diensrekord van maj W.B. Hickie word in The Quarterly Army List for the Period ending 31st December 1914 (Keliher \& Co, Londen 1915) verskaf: 'S. African War, 1899-1902. - Spec. Serv, Offr. (including commd. of Mtd. Inf. Bn. (21 May to 2 Sept 00). Afterwards on Staff, and in commd. of a column. Operations in the Orange Gree State, May 00. Operations in the Transvaal in May and Jun. 00, including actions near Johannesburg and Pretoria. Operations in the Transvaal west of Pretoria, including action at Venterskroon. Operations in Orange River Colony (Aug. to Nov. 00), including actions at Ladybrand (5 Sept.) and Bothaville. Operations in Cape Colony, south of Orange River, 00. Despatches, Lond. Gaz., 10 Sept 01. Brev. of Lt-Col. Queen's medal with 3 clasps. King's medal with 2 clasps ... The War of 1914. - Despatches, Lond. Gaz., 19 Oct 14' (p 2522).

(49) Maurice, F., et al: op cit, p 487.

(50) Amery, L.S., et al: op cit, p 17.

(51) Ibid, $\mathrm{p} 18$.

(52) Maurice, F., et al: op cit, $p 487$.

(53) Pakenham, Thomas: op cit, $p$ 475. Weens die ernstige aard van sy wond is It kol Ross (Durham Light Infantry) as medies ongeskik vir verdere aktiewe diens bevind en huis toe gestuur.

(54) Die dood van kapt William Arthur Glanmor Williams word in M.G. Dooner se ererol (The Last Post) van gesneuwelde offisiere aangegee. Die volgende inligting word verskaf: 'Lieut. Wiliam Arthur Glanmor Williams, D.S.O., 2nd Batt. South Wales Borderers, was killed in action near Bothaville Nov. 6th, 1900. He was born in Sept. 1873, and educated at Clifton College. He was fond of games and a good cricketer .. He served in the operations in the Niger Territories in 1898, including the Benin Hinterland and Siama Expeditions (wounded), being mentioned in despatches and receiving the medal with clasp and the D.S.O. For his services in the South Africa War he was mentioned in despatches, L.G., Sept. 10th, 1901. In the despatch of Gen. Lord Kitchener of May 8th, 1901, the death of Lieut. Williams is mentioned." (p 422).

(55) Amery, L.S., et al: op cit, p 18.

(56) Ibid. In Dooner se ererol word die volgend vermeld: 'Capt Francis Joyce Englebach, 1st Batt. East Kent Regt. (The Buffs), was killed in action near Bothaville, Nov. 6th, 1900. He was born Oct., 1867, and served in the ranks for nearly eight years, gaining his commission in the Buffs June, 1894, being promoted lieut. May, 1897, and capt. April, 1900. He served throughout the operations of the Chitral Relief Force, under Sir Robert Low, 1895, with the 1st Batt. the Buffs, receiving the medal with clasp. He also saw service in the operations on the Niger in 1897-98, including the expedition to Siam, and received the medal with clasp. He was mentioned in despatches, L.G., Sept. 10th, 1901, for his services in South Africa." (pp 111-112).

(57) Pakenham, Thomas: op cit, $p 475$

(58) Amery, L.S., et al: op cit, pp 18-19.

(59) Maurice, F., et al: op cit, p 487.

(60) Ibid, p 488.

(61) Amery, L.S., et al: op cit, p 19. Volgens Amery het die Britse grofgeskut uit 5 artilleriestukke bestaan, nl 4 stukke van $U$. Battery en 'n bykomende pom-pom (Vickers-Maxim). Maurice vermeld egter net 4 kanonne, dws die 2 van It Otter Barry, een van kapt Mair en 'n pom-pom wat op die "wit huis" gevuur het. Pakenham meld dat vier burgers in dié plaaswoning gedood is terwyl die vroue en kinders ongedeerd daarvan afgekom het.

(62) Jackson, M.C., op cit, p 152

(63) Amery, L.S. et al: op cit, p 19. Volgens Dooner se ererol is maj Norman Charles Welch (Hampshire Regiment) in Julie 1865 gebore en het hy aktiewe diens in Burma, Niger en in Suid-Afrika gelewer. Sy naam staan opgeteken in die War Memorial Cloister van Charterhouse in Brittanje (p 412).

(64) Jackson, M.C., op cit, p 153.

(65) Amery, L.S., et al: op cit, pp 19-20. Twee kompanies van 7th Mounted Infantry onder maj H.C. Copernan en kapt C.C. Luard wat die Britse linkerflank moes beskerm, het aan die omtrekbeweging deelgeneem.

(66) Ibid, p 20.

(67) Jackson, M.C.,: op cit, pp 153-154.

(68) Ibid, p 155. Pakenham meld dat die stelling in die varkhok deur ' $n$ bor' ${ }^{\text {h }}$ rdement van $U$. Battery (Otter Barry) uitgewis is ( $p$ 475).

(69) Pahcuham, Thomas: op cit, pp 475-476.

(70) Ibid, p 476

(71) Ibid.

(72) Nierstrasz, P.A.: Der Süd-Afrikanische Krieg 1899-1902, s.j., pp 420 e.v. Met verwysing na die $7 \mathrm{~mm}$ Mauserpatroon, meld hy onder meer die volgende: 'Die Fläche der durch das Geschoss geschlagenen Wunde ist verhältnismäzig klein und diese bei nicht absolut tötlichem Charakter regelmäszig leicht heilbaar.' Oor die berugte dum-dum skrył hy: 'Beim Aufschlag blättert sich der Nickel-Mantel mit dem Weichblei-Kern auf und verursacht so in der Regel eine ungewöhnlich grosze, bösartige, schwere und schwer zu heilende Verletzung.

(73) Pakenham, Thomas: op cit, p 476.

(74) Ibid.

(75) Ibid.

(76) Amery, L.S., et al: op cit, p 20

(77) De Wet, C.R.: op cit, p 320

(78) Ibid. 
(79) Maurice, F., et al: op cit, p 488.

(80) Amery, L.S., et al: op cit, p 20.

(81) Maurice, F., et al: op cit, $p 488$. Vier offisiere het aan hul wonde beswyk, nl It kol Le Gallais, maj Welch, kapt Williams en kapt Englebach. Amery vermeld verkeerdelik die dood van kapt A.S. Peebles wat ten spyte van sy ernstige wond slegs drie weke later weer aktiewe diens verrig het.

(82) Amery, L.S., et al: op cit, p 20.

(83) Vide verwysing 81.

(84) De Wet, C.R.: op cit, p 230.
(85) Dooner, M.G.: op cit, p 215

(86) De Wet, C.R.: op cit, p 228.

(87) Dooner, M.G.: op cit, p 215.

(88) Ibid.

(89) De Wet, C.R.: op cit, p 235. In hierdie verband het hy geskryt: "Maar Bothaville was ons een groote doorn in 't oog, en wij moesten iets doen om met de Engelschen afterekenen.'

(90) Fuller, J.F.C.: The Last of the Gentlemen's Wars, Faber \& Faber, Londen 1937, pp 241-242. 